\title{
1 Constraining the crustal root geometry beneath Northern Morocco
}

2 Díaz, J. ${ }^{(1)}$ Gil, A. ${ }^{(1)}$, Carbonell, R. ${ }^{(1)}$, Gallart, J. ${ }^{(1)}$ and Harnafi, M. ${ }^{(2)}$

3 (1) Institute of Earth Sciences Jaume Almera, ICTJA-CSIC, c/ Solé Sabarís sn, 08028

$4 \quad$ Barcelona, Spain.

5 (2) Institut Scientifique, Université Mohammed V-Agdal, Rabat, Morocco

7 Corresponding author:

8 J. Díaz

9 jdiaz@ictja.csic.es

10 tel: +34934095410

12 Abstract

13 Consistent constraints of an over-thickened crust beneath the Rif Cordillera (N. Morocco) are

14 inferred from analyses of recently acquired seismic datasets including controlled source wide15 angle reflections and receiver functions from teleseismic events. Offline arrivals of Moho16 reflected phases recorded in RIFSIS project provide estimations of the crustal thicknesses in 3D. 17 Additional constraints on the onshore-offshore transition are inferred from shots in a coeval 18 experiment in the Alboran Sea recorded at land stations in northern Morocco. A regional crustal 19 thickness map is computed from all these results. In parallel, we use natural seismicity data collected throughout TopoIberia and PICASSO experiments, and from a new RIFSIS

21 deployment, to obtain receiver functions and explore the crustal thickness variations with a $\mathrm{H}-\kappa$ 22 grid-search approach. This larger dataset provides better resolution constraints and reveals a 23 number of abrupt crustal changes. A gridded surface is built up by interpolating the Moho depths 24 inferred for each seismic station, then compared with the map from controlled source 
experiments. A remarkably consistent image is observed in both maps, derived from completely independent data and methods. Both approaches document a large crustal root, exceeding $50 \mathrm{~km}$ depth in the central part of the Rif, in contrast with the rather small topographic elevations. This large crustal thickness, consistent with the available Bouguer anomaly data, favor models proposing that the high velocity slab imaged by seismic tomography beneath the Alboran Sea is still attached to the lithosphere beneath the Rif, hence pulling down the lithosphere and thickening the crust. The thickened area corresponds to a quiet seismic zone located between the western Morocco arcuate seismic zone, the deep seismicity area beneath western Alboran Sea and the superficial seismicity in Alhoceima area. Therefore, the presence of a crustal root seems to play also a major role in the seismicity distribution in northern Morocco.

\section{$1 \quad$ Introduction}

The Rif Cordillera forms, together with the Betic Range and the Alboran Basin, the so-called Gibraltar Arc System, one of the tightest orogenic arcs on Earth (Platt et al., 2013). This asymmetric curved mountain belt originated during a Miocene continent-continent collision as a result of the westward motion of the Alboran domain between northwest Africa and Iberia. This continental boundary zone is dominated now by the slow convergence between Nubia and Eurasia. However, clear evidences of extensional tectonics can be observed which require a complex geodynamic scenario to be explained. Diverse and often excluding models have been proposed for the area, involving lithospheric delamination (Seber et al., 1996, Calvert et al., 2000a), slab break-off (Blanco and Spakman, 1993, Zeck, 1996), convective removal (Platt and Vissers, 1989) or active eastward subduction of oceanic crust (Gutscher et al., 2002). Currently, there is a certain agreement on models explaining the area as the result of roll-back of a narrow slab of oceanic lithosphere, resulting from the segmentation of the Western Mediterranean Subduction Zone which was active during Oligocene-Miocene times (Royden, 1993, Lonergan 
and White, 1997, Rosenbaum and Lister, 2004, Faccenna et al., 2004, Jolivet et al., 2009, Vergés and Fernàndez, 2012). Nevertherless, large uncertainties remain on major points of such hypothesis. One of the missing knowledge that needs to be fulfilled is on the seismic crustal structure of Morocco, including the topography of the crust-mantle boundary, as very few data are available so far. In the last decade a major effort has been done in this sense, with a significant number of initiatives focused on constraining the regional crustal structure using controlled source experiments, as the RIFSIS (Seismic Investigations across the Rif, Gallart et al, 2012) and SIMA (Active Seismic Investigation across the Atlas; Ayarza et al., 2014) projects. Coeval, large scale projects based on the analysis of natural seismicity, as the Topolberia (Díaz et al., 2009) and PICASSO (Program to Investigate Convective Alboran Sea System Overturn; Platt et al., 2008) initiatives, have also provided relevant information on the crust, even if their main objective has been at lithospheric and upper mantle scale.

This contribution is focused in providing new constraints on the geometrical variations of the crust-mantle boundary beneath North Morocco, using data from active and passive seismic experiments, mostly from the RIFSIS and Topolberia projects. The RIFSIS project involved the acquisition across the Rif domains of two profiles of $\sim 330 \mathrm{~km}$-length oriented N-S and E-W respectively. The interpretation of both profiles in terms of ray-tracing modeling has been presented by Gil et al., (2014). Here, we will focus on the analysis of complementary data mostly coming from offline recordings, that is, the analysis of shot gathers from stations located outside the corresponding profile. Additionally, taking advantage of a coeval, independent experiment in the Alboran Sea (GASSIS-Westmed project, Gracia et al., 2012) focused in the acquisition of multichannel reflection seismic profiles, we have used inland recordings of air-gun shots fired along the marine transects by the Spanish research vessel, Sarmiento de Gamboa.

Concerning natural seismicity, we built up a large database from broad-band stations deployed over the area in different experiments, and we used teleseismic receiver functions (RF) to 
estimate crustal depths. The contributing data came not only from the whole periods where the TopoIberia and PICASSO deployments were active, but also from a more recent deployment of 13 stations in the Rif domains within the RIFSIS project. Previous work on the area dealing with RFs (Mancilla et al. 2012, Thurner et al. 2014, Mancilla and Diaz, 2015) came only from first datasets gathered within the former projects.

\section{Geological and Geophysical setting}

The Rif Cordillera, similarly to the Betic Ranges and other Alpine Mediterranean cordilleras, includes the Internal and the External Zones, separated by Flysch units (Chalouan et al., 2001, 2008). The Internal zones are formed by Paleozoic, Mesozoic and Cenozoic sequences affected by Alpine deformation. The External Zones are formed by units with generally carbonate and pelitic Mesozoic and Cenozoic series, and form a fold-and-thrust belt detached along the Late Triassic evaporitic beds from the thinned continental crust of the North Africa margin. The Flysch units are mainly composed of Cretaceous-Lower Miocene detritic rocks. The main reliefs of the Rif Cordillera are the result of recent compressional structures related to Eurasian-African convergence developing since the Late Miocene.

The main geodynamical feature in the upper mantle is the presence of a step fast velocity slab beneath Alboran, reaching depths close to $600 \mathrm{~km}$. This body, already imaged by Blanco and Spakman (1993) and Spakman and Wortel (2004), has been clearly mapped in the new teleseismic tomographic images obtained from the exploitation of the Topolberia and PICASSO datasets (Bezada et al., 2013, 2014, Bonnin et al., 2014). Those images suggest that the almost vertical slab tears beneath the Eastern Betics, hence providing an explanation of the uplift rates observed in this zone (Garcia-Castellanos and Villaseñor, 2011). Data from SKS splitting (Buontempo et al., 2008, Diaz et al., 2010, Miller et al., 2013) have evidenced a spectacular 
rotation of the inferred fast polarization directions along the Gibraltar arc, interpreted as an evidence of asthenospheric mantle flow deflected around the Alboran Sea fast velocity slab (Alpert et al., 2013, Diaz and Gallart, 2014). Studies based on GPS observations from both permanent and non-permanent sites (Fadil et al., 2006, Vernant et al., 2010, Koulali et al., 2011, Palano et al., 2013) have shown a previously unexpected south to southwest escape of the Rif region, which is interpreted as a wide transpressive zone. To account for those observations, Pérouse et al. (2010) presented a geodynamical model involving dragging from the slab beneath eastern Rif, resulting in a crustal thickening beneath this area. A similar hypothesis, involving an attached slab pulling down the crust beneath the eastern Rif, has been retaken by Palomeras et al. (2014) to explain the recent surface wave tomography models for the western Mediterranean region.

Very scarce seismic profiles beneath the Rif Cordillera and surrounding regions are available, resulting in a poor knowledge of the crustal structure. First explorations carried out in the 1970s using low-dense refraction seismics (Hatzfeld and Bensari, 1977), suggested $30 \mathrm{~km}$ crustal depths towards the Gharb Basin. Beneath the Alboran Sea, early wide-angle profiles inferred Moho depths of 18-20 km beneath the central part of the basin (Working Group for Deep Seismic Sounding., 1978). In the late 1980s, new explosion seismic investigations were carried out across the High and Middle Atlas (Wigger et al., 1992), leading to Moho depths close to $35 \mathrm{~km}$ beneath the southern limit of the Rif domain.

Crustal models based on the interpretation of elevation and gravity data, in some cases combined with heat flow, geoid and petrological have shown a moderately thick crust underneath the Rif and Betics $(\sim 32-34 \mathrm{~km})$, whereas a thin continental crust $(\sim 18-22 \mathrm{~km})$ characterizes the Alboran Basin (Torne et al, 2000, Zeyen et al., 2005, Fullea et al. 2014). Normal incidence MCS reflection data has shown that the Alboran basin shows a progressively thinning towards the East, reaching $15 \mathrm{~km}$ in the East Alboran basin and $6 \mathrm{~km}$ further East, in the Algero-Balearic oceanic basin 
124 (Booth-Rea et al., 2007). The geometry of the Moho beneath Northern Morocco has been

125 investigated using the receiver function methods, mostly from the TopoIberia and PICASSO

126 datasets. Beneath the Rif Cordillera, crustal thickness range from 35 to $53 \mathrm{~km}$, while the

127 northeastern part of Morocco the Moho clearly thins to reach values of 22-30 km (Mancilla et al.,

128 2012, Thurner et al., 2014). The eastern limit of the Rif cordillera, in the transition between both

129 areas, show complex signals admitting different interpretations, but clearly stating the presence of

130 a large crustal root. At subcrustal levels, Thurner et al. (2014) observed a negative polarity RF

131 event beneath the eastern Rif, which has been interpreted as a shallow, recently formed,

132 lithosphere-astenosphere boundary (LAB).

133 Concerning the velocity structure, most of the available constrains come from regional

134 tomographic studies. Travel time tomographies based on local seismicity recently obtained

135 beneath the Gibraltar Arc system (El Moudnib et al., 2015) have shown low velocity anomalies at

136 depths around $30 \mathrm{~km}$ beneath the Betics and the Alhoceima region. This low velocity is

137 interpreted as a crustal root extending along the entire Gibraltar Arc, from the easternmost Betics

138 to the SE edge of the Rif Cordillera. Calvert et al. (2000b) and Serrano et al. (2005) have imaged

139 a robust low-Pn velocity anomaly beneath the Betics and a smaller one beneath the Rif and

140 Middle Atlas, while the Alboran Sea shows normal velocity values. Recent Pn and Sn

141 tomographies of the Euro-Mediterranean region (Diaz et al., 2013) confirm this pattern and show

142 a local region of high $\mathrm{Pn}$ and Sn velocity beneath the Alhoceima region (approx. $35^{\circ} \mathrm{N}, 3^{\circ} \mathrm{W}$ ).

\section{Data acquisition and processing}

145 The RIFSIS project targeted the seismic structure along different domains of the Rif Cordillera

146 from the acquisition, in October 2011, of two $330 \mathrm{~km}$-long wide-angle profiles oriented

147 respectively $\mathrm{N}-\mathrm{S}$ and $\mathrm{E}-\mathrm{W}$. The geometry and dimensions of the Rif Cordillera are not 
148 favorable to perform a WA seismic profile perpendicular to strike of structures and hence, the

149 Bouguer anomaly pattern was primarily taken as main reference for implementation of the

150 profiles (Figure 1). Southwards, the N-S profile connects and overlaps with the SIMA transect

151 across the Atlas, recorded in 2010 (Ayarza et al., 2014). Jointly, the SIMA and the NS-RIFSIS

152 line delineate a $700 \mathrm{~km}$-long wide-angle seismic profile across the Betic-Rif-Atlas system. The

153 use of a total of 810 Reftek 125a (Texans) instruments from the IRIS-PASSCAL instrument

154 center allowed to achieve a relatively high lateral resolution, with an average station spacing of

$155750 \mathrm{~m}$. These autonomous seismic stations recorded the energy released by 5 shots roughly

156 spaced $100 \mathrm{~km}$. Each shot consisted in $1 \mathrm{Tn}$ of explosive distributed in two $50 \mathrm{~m}$ boreholes. Gil

157 et al., (2014) have interpreted the two profiles using ray-tracing modeling (Zelt and Smith,

158 1992). This analysis resulted in two detailed velocity-depth $2 \mathrm{D}$ models that represent a

159 significant upgrade on the crustal structure knowledge beneath this area. The most relevant

160 result is the identification of a large, clearly defined Moho step both in East-West and North-

161 South directions, delimiting an area of crustal thickening, roughly coincident with the Bouguer

162 anomaly. This crustal root, well constrained from both profiles, reaches values of 47-50 km

163 below the external Rif domain. To the east of the Nekkor fault, the crust thins abruptly down to

$16420 \mathrm{~km}$ and to the south towards the Middle Atlas, the crust thins smoothly.

165 The deployment logistics of the RIFSIS experiment was designed so that all the stations deployed

166 along the N-S and E-W profiles were able to record all the shots fired within each profile, thus

167 resulting in both online and offline shot records (Figure 1a). As previously stated, this

168 contribution focuses in the investigation of these offline data, with the aim to produce a detailed,

169 comprehensive map of the crustal thickness in northern Morocco. In a first step, the data have

170 been processed following an ad hoc conventional normal incidence approach. Low fold wide-

171 angle stacks can be obtained also with shot records featuring very long offsets (Gallart et al.,

172 1995, Carbonell et al., 1998). A relatively simple processing sequence has been applied to 
173 increase the signal-to-noise ratio of the data. This consists of band pass frequency filtering,

174 spherical divergence amplitude corrections, spectral whitening and amplitude gain. Following

175 Carbonell et al. (2002), a hyperbolic time reduction has been applied. Common-mid-points

176 (CMP) geometry has been calculated from the acquisition geometry and used to sort for CMP and

177 stack. The average velocity applied in the hyperbolic correction was chosen so that the reflections

178 from the Moho appear as subhorizontal events (Figures 2 and 3). The specific acquisition

179 geometry allows for the determination of several low fold stacks in different directions, hence

180 placing 3D constraints on the crustal structure beneath the Rif orogen.

181 A second and complementary analysis arises from the identification and reading of the PmP phase

182 arrivals in all the offline fan shot gathers. Although the PmP arrivals in these sections are in cases

183 less prominent than the ones observed in the in-line transects, some relatively high amplitudes can

184 be identified and their time-arrivals can be extracted. Assuming a uniform crust with a mean

185 velocity value of $6.2 \mathrm{~km} / \mathrm{s}$, the depth of the reflection point can then be calculated and assigned to

186 the midpoint between the shot and the receiver positions. These assumptions imply that

187 significant errors may arise in case of heterogeneities, but we will show that this method still

188 provides meaningful results.

189 An independent survey in the Alboran Sea, from the GASSIS-Westmed project, was coincident

190 in time with the RIFSIS in-land profiles described above. This marine survey focused on the

191 investigation of the crustal structure beneath the Alboran basin through the acquisition of a set

192 of vertical incidence seismic profiles. These data was acquired by the Spanish RV Sarmiento

193 de Gamboa equipped with an air-gun source array and a $6 \mathrm{~km}$ streamer. Therefore, a

194 coordination and logistical effort was carried out within RIFSIS teams so that onshore wide-

195 angle receiver gathers could be recorded using the offshore shots (Figure 1). The complexity of

196 the area make the detailed interpretation of the records difficult, but preliminary models have

197 been presented by Cembroski et al. (2013). Here, we have only retained the Moho depths 
around the onshore-offshore transition from GASSIS profiles 17, 19 and 21 (Figure 1a). The

199 analysis followed the main lines described previously for the offline profiles inland;

200 identification of PmP phases, extracting their time and calculating an approximate crustal

201 thickness at the corresponding midpoint. Near to the eastern end of Morocco, we have also

202 applied this approach to estimate the crustal depths along a N-S oriented wide-angle profile

203 running from Almeria to Nador acquired in the framework of the TopoMed project (Galvé et

204 al., 2007).

205 Concerning natural earthquake data, we have used the database from the Topolberia and 206 PICASSO experiments for a classical P-wave receiver function analysis. This method analyzes

207 the seismic phases converted at high impedance seismic discontinuities beneath the station and 208 infers an estimation of the depth of this conversor. We benefit here from a more extended 209 database dealing with receiver functions (RF) with respect to previous works on this area already 210 published. Most of the stations used in TopoIberia have been kept in the area and active until 211 2013, in the framework of the RIFSIS project, and hence provided additional data to those 212 analyzed by Mancilla et al. (2010). Additionally, a set of 13 stations from the same pool of 213 instruments was redeployed in late 2013 to cover those areas where anomalous features were 214 inferred from the so-far available results. The number of valid measurements for these stations is 215 limited due to the short time duration of the deployment (around 6 months), but their results do 216 contribute to a better-constrained image of the sharp Moho depth variations. Figure $1 \mathrm{~b}$ shows the 217 location of all the investigated sites.

218 The teleseismic events have been selected based on standard criteria: (1) events with 219 magnitudes higher than 5.5 (2) epicentral distances between $30^{\circ}$ and $90^{\circ}$ to avoid wavefield 220 complexities that likely arise from upper mantle discontinuities or diffraction at the core221 mantle boundary, and (3) high signal-to-noise ratio (SNR) allowing the identification of clear P 222 arrivals. Most of the sites investigated by Mancilla et al., (2010) have been reanalyzed, 
considering additional data when available. All the PICASSO and the 13 redeployed

224 'Topolberia' stations have been analyzed from scratch. The number of retained RF for each of the investigated stations ranges between 50-60 RFs for the originally deployed TopoIberia sites and 7-26 RFs for the redeployed ones. The PICASSO sites typically provide an intermediate number of retained RFs, ranging between 15 and 41 . Whenever possible, the crustal depth $(\mathrm{H})$ and the $\kappa$ ratio $\left(\kappa=\mathrm{v}_{\mathrm{p}} / \mathrm{v}_{\mathrm{s}}\right)$ beneath each station has been derived from the application of the $\mathrm{H}$ $\kappa \square$ method (Zhu and Kanamori, 2000). This method, nowadays widely used, considers a mean crustal velocity and estimates the arrival time of the Ps, PpPs and PsPs phases for each given combination of $\mathrm{H}$ and $\kappa$. The amplitude of the real RFs at those times is then evaluated in the $(\mathrm{H}, \square \kappa)$ parameter space. The presence of a well-defined maximum in the stacking surface defines the preferred solution for each station. However, this method is known to have 234 limitations in the presence of a dipping conversor (Julià et al. 2003, Lombardi et al. 2008), a 235 gradient-type boundary or in presence of sedimentary basins (e.g. Zelt and Ellis, 1999). In a 236 limited number of sites, this method is not applicable due to weak Moho conversions or to a 237 lack of clear multiples. In those cases, we estimate the crustal thickness by picking the Ps 238 arrival in the summation trace after applying a Ps-moveout correction to the reference ray 239 parameter of $0.065 \mathrm{~s} / \mathrm{km}$. Delay times are then converted to depth using an average Vp/Vs 240 ratio, calculated at stations belonging to the same domain. Some stations provide complex 241 results including two close conversors. On those cases, the general rule has been to interpret 242 the deeper conversor as the Moho; nevertheless, each particular case has been analyzed in 243 detail. Following a classical approach (e.g. Spada et al., 2013), the measurements have been 244 classified in three categories defined as: (a) clear conversion phase and multiples for most of

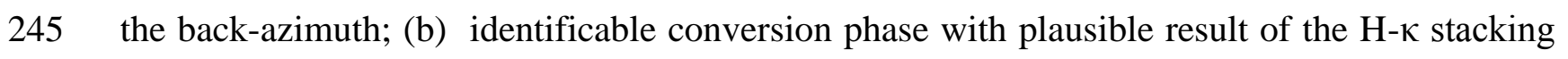
246 method; (c) use of the Pms travel time to obtain the crustal thickness. Half of the retained 39 
new and reanalyzed crustal thickness estimations are classified as " $\mathrm{A}$ ", $28 \%$ as "B" and about $24820 \%$ as "C".

\section{$4 \quad$ Results and Discussion}

\subsection{Active seismics}

The Moho discontinuity is clearly imaged in the low fold wide-angle stacks along the main EW and the NS profiles. Along the EW stack section (Figure 2a) the Moho is imaged with high energy in most areas of the profile covered by two shots, except beneath shot-points R3 and R5, where the lack of coverage does not allow a proper identification. The western part of the section shows a Moho discontinuity located around $15 \mathrm{~s}$, corresponding to depths close to 47 $\mathrm{km}$ assuming a typical mean crustal velocity of $6.2 \mathrm{~km} / \mathrm{s}$. In the eastern half, the PmP phases arrive clearly earlier, around $10 \mathrm{~s}$ corresponding to crustal thickness around $33 \mathrm{~km}$. Therefore, the differences in arrival times $-15 \mathrm{~s}$ vs $10 \mathrm{~s}$ - and/or the estimated depths $-47 \mathrm{~km}$ vs $33 \mathrm{~km}$ constitute solid evidence of a significant heterogeneity in the deeper part of the crust and mantle transition.

In the NS stack section (Figure 2b) the Moho is imaged as a high amplitude event at the southern part of the profile (from CDPs 850 to 1100) reaching depths of 35 to $40 \mathrm{~km}$ below the 264 transition from the Moroccan Meseta to the External Rif. To the North, the Moho deepens and reaches estimated depth of approximately $46 \mathrm{~km}$, and then it becomes subhorizontal for over $100 \mathrm{~km}$ beneath shots R3 and R2 (see Figure 1 for location). In all this area beneath the External Rif domain the Moho reflection is weaker. The northernmost part of the section images a horizontal Moho as a relatively weak event at approximately $43 \mathrm{~km}$ depth. The 269 differences of reflected energy along the NS profile evidence again high crustal heterogeneity. This seismic signature can be understood as the effect of sampling different tectonic domains. 
Figure 3a shows the low-fold wide-angle stack calculated using the seismic signals of shot R2 recorded by the instruments located along the RIFSIS EW profile. The corresponding CMP transect that can be constructed with this records samples the Moho along an approximately EW oriented profile across the Central Rif (labeled EW01 in Figure 1a). In this wide-angle stack, to the East, the Moho is identified around 12s, and it most probably corresponds to depths around $35 \mathrm{~km}$. Further West, the Moho deeps down to at least $50 \mathrm{~km}$ beneath CMP 30375. The Moho depth then decreases smoothly reaching $43 \mathrm{~km}$ in the western termination of the profile. Note that in the western section of this profile, a secondary arrival is consistently observed around $30 \mathrm{~km}$. Taking into account the recording offsets for these stations, which range from 70 to $135 \mathrm{~km}$, and the phases observed in the record sections along the E-W profile, these early arrivals are interpreted as an intra-crustal phase associated with the top of the lower crust.

Figure $3 \mathrm{~b}$ show a NS section constructed from the signals of shot R4 recorded along RIFSIS profile NS. The sample area is depicted as NS01 in Figure 1a. As in the previous case, significant differences in the time arrivals of the interpreted PmP phases can be observed. The Moho reflectivity imaged by the NS01 pseudo-profile is more laterally continuous and features higher amplitudes than in the main NS section (Figure 2b), although the observed Moho geometry is similar in both cases. In the southern part of the NS01 section, the Moho is clearly imaged at $13 \mathrm{~s}$ corresponding to depths around $40 \mathrm{~km}$. Northward, the Moho deepens and reaches values exceeding $45 \mathrm{~km}$ near the junction with the previously discussed EW01 pseudoprofile. Further to the north, the PmP arrivals are not so prominent, but still reveal a crust that thins quickly to reach values close to $40 \mathrm{~km}$. A marked difference in Moho reflectivity is evidenced when comparing the main NS profile and the NS01 pseudo-profile. The main profile only shows strong reflectivity at its southernmost termination, while NS01 shows a strong reflector between the 40200 to $40450 \mathrm{CDPs}$, located at similar latitudes. Taking into account 
that both sections are sampling similar geological domains, the reflectivity differences

297 evidenced should be attributed either to differences in the efficiency of energy propagation at 298 the vicinity of the shot-points, or to crustal differences in seismic attenuation along travel 299 paths.

The large variations in crustal thickness observed in the low fold stacks are consistent with the ray-tracing models obtained by Gil et al. (2014) along the N-S and E-W RIFSIS profiles (Figure 4a), which revealed a large Moho step and an area of crustal thickening both in EW and NS directions, grossly coincident with the Bouguer gravity anomaly (Figure 1b). The RIFSIS EW profile shows a thin crust beneath NE Morocco, with thickness around $30 \mathrm{~km}$ depth which increase West of Nekkor fault, to reach $52 \mathrm{~km}$. The EW01 profile here presented, is located about

$30730 \mathrm{~km}$ north and show similar overall results. However, EW01 evidences an even thicker crust northwards of the main EW profile, in the area between shot-points R3 and R4. Along the NS profile, the new profile NS01 shows Moho depths in the central part of the profile exceeding 50

$310 \mathrm{~km}$, consistent with with the image retrieved from profile EW01 at the crossing area.

311 Figure $4 \mathrm{~b}$ shows some examples of the PmP phases identified in the different fan gathers, used to 312 estimate crustal thickness offline of the main profiles. The PmP arrivals from shot R4 recorded 313 along line 5000 sample a zone located at $4^{\circ} \mathrm{W}$ and arrive at $3-4 \mathrm{~s}$ reduced time, suggesting a crustal 314 thickness around $30 \mathrm{~km}$ and marking the eastern limit of the thickened area. The PmP phases 315 from the same shot recorded along line 4000 arrive at 3-6 s reduced time for distances around 130 $316 \mathrm{~km}$, marking a clearly thickened area (Figure 4b, upper panel). The fan-like section from shot R4 317 recorded along line 3000 shows remarkable strong variations in the PmP arrival times, hence in 318 crustal thickness (Figure 4b, lower panel). PmP arrivals are identified at about $2 \mathrm{~s}$ reduced times in station 3011, located at $135 \mathrm{~km}$ offset from shot-point, then travel times increase steeply, 
reaching unusual values of $7 \mathrm{~s}$ at about $145 \mathrm{~km}$ offset. This corresponds to crustal depths of 50-55

$321 \mathrm{~km}$ for midpoints located in the area already sampled by pseudo-profile EW01.

322 Data from the PmP phases form the GASSIS Profile 21 (see Figure 1) provide clear evidences 323 of a deep Moho beneath the coastline and extending few kilometers offshore, with depths 324 exceeding $55 \mathrm{~km}$. On the other hand, the NW-SE oriented profiles 17 and 19, sampling eastern 325 Morocco, show a Moho deepening smoothly beneath the coastline to depths of about 40-45 $326 \mathrm{~km}$. The crustal thickness beneath the Alboran Sea varies between 17 and $20 \mathrm{~km}$. Data from the 327 N-S oriented WestMed profile in eastern Morocco show a Moho gently deepening from $18 \mathrm{~km}$ 328 in the center of the Alboran Sea to $28 \mathrm{~km}$ inland, consistent with the depth estimates reported 329 here.

As a final step, all the Moho depth estimations have been integrated in a grid file using a the nearest neighbor algorithm included in the GMT package (Wessel et al., 2013), using a small 332 search radius to avoid extrapolations. The resulting map is presented at Figure 6a for comparison with the one resulting from the RF analysis (see next section). The thickest crust zone is not

334 limited to the central Rif zone but extends northwards up to the coastline, within a limited region close to the Beni Moussera peridotites. A significant variation in the Moho depth estimation appears at this zone, as the deep Moho imaged derived from the land recording of profile 21 is 338 interpret that in the first case we are sampling the thickened Rif crust, while in the second case the 339 origin of the observed phases is the lower limit of the thin Alboran crust that probably indents the 340 thicker Rif crust. The Moho map derived from controlled source seismic data also evidences the 341 progressive thinning to the East already described by Gil et al. (2014). 
Figure 5 presents some representative examples of the HK analysis. PM07 (Figure 5a) is a good example of the HK results for stations located in the central part of the Rif domains, illustrating the thick crust observed under this region. Ps arrives at 5.6s, a delay consistent with the $44 \mathrm{~km}$ crustal thickness derived from the HK grid search. M416, located also in the Rif Domain, shows a more complex image (Figure 5b). The stacked RF shows two maxima at $4.2 \mathrm{~s}$ and $6.4 \mathrm{~s}$, corresponding to depths of approximately 34 and $54 \mathrm{~km}$. Taking into account the consistency of 350 the Ps arrival over the different backazimuths, we have identified the Moho with the first conversor. M418 (Figure 5c), located close to the Nekkor Fault area, shows a clear maximum in the grid search, resulting in a crustal thickness of $30 \mathrm{~km}$ and illustrating the eastward thinning already inferred from active seismic results. Finally, station PM20 (Figure 5d), located in the southern part of the investigated area, close to the Middle Atlas, shows again a clear result, with 355 the Moho conversor located at $30 \mathrm{~km}$, thus marking the southern termination of the thickened crust.

357 Consistently with results from active source experiments, the RF analysis evidences a very thick crust beneath the central part of the Rif Cordillera, with Moho depths close to $50 \mathrm{~km}$.

359 Although the results are somehow ambiguous for some sites, well-defined converted phase 360 arriving with large time delays are often observed, supporting the existence of this significant 361 crustal root. The results presented here show an overall similarity with those published by 362 Mancilla et al. (2012), Thurner el al., (2014) and Mancilla and Diaz (2015), even if significant 363 differences arise at some areas. Mancilla et al. (2012) present two alternative interpretations for 364 stations in central Rif and they favor the model attributing thickness of $27-41 \mathrm{~km}$ to stations 365 M013 and M006. Under this zone, RF's determined from the additional data provided by the 366 new deployments favor an interpretation in which Moho is associated to the latest 367 arrival/conversor. This results in crustal thicknesses over $50 \mathrm{~km}$. Further East, Mancilla et al. 368 (2012) estimated a crustal thickness of $26 \mathrm{~km}$ beneath M007, but the contribution of the new 
data sets favor a thicker value of approximately $42 \mathrm{~km}$. The later is more consistent with the

370 result inferred for PM36, located a few kilometers to the north. M007 is located close to the

371 Nekkor fault area, a sharp limit between thick and thin crusts. These large differences between

372 the interpretations are mainly due to the existence of the two conversors. Either of them can be 373 interpreted as being the Moho. This is only relevant for the precise mapping of the eastward 374 crustal thinning, but does not change the global image derived from those results.

375 The good regional coverage and fairly dense station spacing ( $60 \mathrm{~km}$ for TopoIberia stations, and $\sim 30 \mathrm{~km}$ for PICASSO stations) allows interpolating and extending single station measurements into a continuous map of crustal thickness for the entire study area (Figure 6b). To allow for a direct comparison, we have used the same interpolation scheme and color scale than for the map derived from active source experiments (Figure 5a). Both maps are

380 remarkably similar, taking into consideration that they come from completely independent data 381 sets and methodologies.

\subsection{Joint interpretation}

384 Results from active seismics and RFs are joined to obtain the final crustal thickness map of north 385 Morocco, presented in $2 \mathrm{D}$ and $3 \mathrm{D}$ views at Figure 7. As previously stated, the main feature is the 386 large crustal root beneath the central Rif Domain that reaches, at least, $50 \mathrm{~km}$. This root is in good 387 agreement with the area presenting large negative Bouguer anomaly values reaching values close 388 to $-150 \mathrm{mGal}$. The crustal thickness estimations arising from RF and active seismic show 389 generally differences laying in the usually admitted error range (e.g. Spada et al., 2013). The main 390 exception occurs beneath the central Rif Domain, where the differences are significant even if 391 both methologies consistently show a crustal root. Those differences can be related to the complex crustal geometry, resulting in weak and complex RFs and PmP phases which do not

393 allow simple evaluations based in oversimplified hypotheses. Therefore, the absolute values of 
the crustal thickness in this area can not be resolved precisely. The controlled source seismic data extend this root until the coastline in a limited region close to $5^{\circ} \mathrm{W}$, near the Beni-Boussera peridotites (Azdimousa et al., 2013, Romagny et al., 2014). This shallow peridotitic body has only a moderate expression in the Bouguer map, clearly smaller than the anomaly observed in the Ronda peridotites, located in the Betic side of the Gibraltar Arc. We attribute this difference to the effect of a large crustal root below BeniBoussera, that counteracts the high density bodies close to the surface.

Most of the available tectonic reconstructions of the Gibraltar Arc (Vergès and Fernandez, 2012, van Hinsbergen et al., 2014, Chertova et al., 2014) support the hypothesis of a west directed slab rollback in the western Mediterranean. Recent teleseismic body-wave tomographic models (Bezada et al., 2014, Bonnin et al 2014) show that the Alboran slab can hardly be identified above depths around $100 \mathrm{~km}$ beneath the Betics, while it is clearly imaged beneath the Rif, where it seems to be connected to the surface. This geometry supports the presence, already pointed out by Spakman and Wortel (2004), of slab tearing beneath the eastern Betics but not beneath the Rif. Palomeras et al. (2014) have presented a surface wave tomography that shows evidences of an attached slab beneath the central part of the Rif. Pérouse et al. (2010) and Petit et al. (2015) reached a similar conclusion, based respectively in the modeling of GPS data and in the analysis

411 of the degree of isostatic compensation of the Rif topography. The thickened crust area mapped by our data is coincident geographically with the area where an attached slab has been proposed.

413 The limited lateral dimension of the thickened area, altogether with the large thickness 414 observed, exceeding 50-55 km, seems to favor the hypothesis presented by Petit et al. (2015), 415 suggesting that the crustal thickening is a local, dynamic response to the sinking of the Alboran 416 slab. In this model, the slab, still attached beneath the Rif but progressively detaching and 417 sinking into the mantle nearby, promote lower crust flow that results in local thickening as the 418 crust is sucked to overcome the void created above the mantle hinge. 
419 To the East, the Nekkor fault area shows a major and rather sharp change in crustal thickness.

420 This surface feature denotes the limits of the overthickened zone and can be associated with the 421 position of the Neo-Tethys passive margin created during the Mesozoic rifting (Gomez et al., 422 2000, Tesón, 2009) connected with the TransAlboran Shear Zone. This feature marks the 423 boundary and/or sharp change of other geophysical observables. For example, it is coincident 424 with the limit of the seismic activity, the margin of the Bouguer anomaly and/or is a localized 425 marker of the change in the anisotropic parameters. These characteristics or boundary markers suggest that the Nekkor fault is, most probably, a lithospheric-scale structure.

The limit of the seismicity in the area can be observed in Figure 7, where the hypocentral distribution during the period 2000-2014, as reported in the IGN catalogue, is overlaid on the determined map of crustal thickness. Main points are the presence of a well defined, N-S oriented, alignment of deep seismicity in the westernmost Alboran Sea (approx. $4.6^{\circ} \mathrm{W}$ ) and a large amount of superficial seismicity distributed around the Alhoceima region $\left(4^{\circ} \mathrm{W}, 36^{\circ} \mathrm{N}\right.$ approx.) and south of Nador $\left(3^{\circ} \mathrm{W}, 36^{\circ} \mathrm{N}\right)$. To the West a horseshoe/arcuate alignment of seismicity, including both superficial and deep events can be defined from about $5.5^{\circ} \mathrm{W}, 34.5^{\circ} \mathrm{N}$ to $7^{\circ} \mathrm{W}, 35.5^{\circ} \mathrm{N}$. The origin of this seismicity remains unclear, and is, currently, under investigation. The installation of several permanent stations in Morocco should help in resolving correctly the location of these hypocenters. It is worth to point out that the zone with thickened crust lacks seismicity and corresponds to the area in-between the seismically active regions. Few events have been located so far inside the region defined by the $40 \mathrm{~km}$ depth

440 isoline. The relationship between the crustal thickening, the seismic gap and the presence of an 441 attached slab is still an open issue to be explored in the next future. 


\section{Conclusions}

445 The analysis presented here of new seismic data including controlled source wide-angle and 446 natural seismicity places constrains on the 3 dimensional geometry of the base of the crust 447 beneath northern Morocco. The Moho depth map built up by joining the two independent 448 datasets provide a remarkably consistent image of the 3D crustal variations, clearly dominated 449 by the presence of a large crustal root beneath central Rif.

450 Offline data from controlled source seismic profiles has been processed in order to obtain 451 information on the crustal thickness variations offline the main seismic profiles, thus extending 452 to 3D the 2D crustal models presented by Gil et al. (2014). CMP sorting of the records 453 corresponding to the offline shots of the RIFSIS transects results in pseudo-profiles sampling 454 intermediate zones. Low fold wide-angle stacks were then obtained after applying a hyperbolic 455 move-out to the shot records. The Moho geometry can then be extracted from these images. 456 We also estimated the crustal thickness from PmP phases identified in fan gathers of the 457 RIFSIS land shots and in the stations deployed inland to record the offshore shots of the marine 458 MCS profiles of the GASSIS experiment. At the same time, teleseismic RFs in the Rif domain 459 area were analyzed, to determine the crustal thickness beneath northern Morocco. We 460 reprocessed data from both the Topolberia and PICASSO experiments and installed some 461 additional stations to densify the data in the more complex region of interest. The technique of 462 H-א stack was used to extract the depth location of the Moho discontinuity beneath each 463 seismic station obtaining an independent crustal thickness map. Even if some differences do 464 exist, the two crustal thickness maps are remarkably consistent, taking into account that two 465 completely independent methods were used. The controlled source wide-angle seismic data 466 sample the Moho Moho discontinuity from above using reflected phases and in the RFs approach the depth of the Moho is probed from bellow. 
Both maps resolve the 3D geometry of the Moho. The major achievement of this study is that the

469

470

471

472

473

474

475

476

477

478

479

480

481

482

483

484

485

486

487

488

489

490 geometry of the large crustal root is well documented in the central part of the Rif Cordillera. The area with thicker crust is located around $4.5^{\circ} \mathrm{W}, 35^{\circ} \mathrm{N}$, a zone not directly imaged by the RIFSIS models. Both controlled source and natural seismicity data suggest that a crustal root extends to the coastline in a limited region close to $5^{\circ} \mathrm{W}$, around the Beni-Boussera peridotites. The global image is consistent with the Bouguer anomaly map, even if the location of the crustal thickness maximum seems shifted to the Northeast. The area with larger crustal depth is coincident geographically with the zone where independent studies based on P-wave and surface wave tomography, and GPS modeling have suggested that that the Alboran fast velocity slab can be attached to the crust. Therefore, we interpret that the observed crustal thickening is directly related to the pull exerted by the high velocity Alboran slab.

Furthermore, the Moho-depth map presented reveal that the regions with crustal thicknesses of $40 \mathrm{~km}$ define an area with a small amount of seismicity, between the arcuate seismicity beneath western Alboran Sea and the more superficial seismicity in the Alhoceima area. Therefore, the presence of a crustal root seems to play a major role in the seismicity distribution in northern Morocco.

\section{Acknowledgements}

Funding for this project has been available from Spanish Ministry of Science and Innovation under grants: CGL2009-09727 (RIFSIS), CSD 2006-00041 (TopoIberia), CGL2007-63889 (SIMA), CGL2008-3474 (TopoMed), and by Generalitat de Catalunya grant: 2009SGR996. We have also used data from the PICASSO project, founded by the U.S. NSF grant EAR0808939. 
491 We thank Bureau Gravimétrique International (BGI)/IAG International Gravity Field Service

492 (http://bgi.obs-mip.fr ) for facilitating the gravity data in the North Morocco and Iberia.

493 reau 


\section{References}

495

496

497

498

499

500

501

502

503

504

505

506

507

508

509

510

511

512

513

514

Alpert, L.A., Miller, M.S., Becker, T.W., and Allam, A. (2013). Structure beneath the Alboran from geodynamic flow models and seismic anisotropy, J. Geophys. Res., 118, 4265-4277, doi:10.1002/jgrb.50309.

Ayarza, P., R. Carbonell, A. Teixell, I. Palomeras, D. Martí, A. Kchikach, M. Hanafi, A. Levander, J. Gallart, M.L. Arboleya, J. Alcalde, M. Charroud and M. Amrhar (2014), Crustal thickness and velocity structure across the Moroccan Atlas from long offset wide-angle reflection seismic data: the SIMA experiment, Geochem. Geophys. Geosyst., 15, 1698-1717, doi:10.1002/2013GC005164.G3.

Azdimousa, A. J. Bourgois, G. Poupeau, M. Vázquez, L. Asebriy and E. Labrin (2013), Fission track thermochronology of the Beni Bousera perifotite massif (Internal Rif, Morocco) and the exhumation of ultramafic rocks in the Gibraltar Arc, Arab. J. Geosci., doi:10.1007/s12517-0130924-3

Bezada, M.J., E.D. Humphreys, D.R. Toomey, M. Harnafi, J.D. Dávila, and J. Gallart, (2013), Evidence for slab rollback in westernmost Mediterranean from improved upper mantle imaging, Earth and Planetary Sciences Letters, 368, 51-60. doi: 10.1016/j.eps1.2013.02.024

Blanco MI, Spakman W (1993) The P wave velocity structure of the mantle below the Iberian Peninsula: evidence for subducted lithosphere below Spain. Tectonophysics 221, 13-34, doi:10.1016/0040-1951(93)90025-F.

Buontempo, L., G.H.R Bokelmann, G. Barruol and J. Morales, (2008). Seismic anisotropy 

Alguacil, and N. Jabour (2000a), Geodynamic evolution of the lithosphere and upper mantle beneath the Alboran region of the western Mediterranean: Constraints from travel times tomography, J. Geophys. Res., 105, 10,871-10,898.

Calvert, A., E. Sandvol, D. Seber, M. Barazangi, F. Vidal, G. Alguacil and N. Jabour (2000b). Propagation of regional seismic phases [ $\mathrm{Lg}$ and $\mathrm{Sn}$ ] and Pn velocity structure along the AfricaIberia plate boundary zone: tectonic implications. Geophys. J. Int. 142, 384-408

Carbonell, R., J. Gallart and A. Pérez-Estaún (2002). Modelling and imaging the Moho transition: the case of the southern Urals. Geophys. J. Int., 149, 134-148 crustal trnasiction at the Westernmost Mediterranean from seismic profiling, Geophys. Res. Abs., Vol 15, EGU 2013-8209 presented at 2013 spring Meeting EGU, Vienna, Austria, April. mountain building (Morocco): a new tectonic scenario, Bull. Sec. geol. France, 172(5), 603616. Saddiqi, The Rif Belt. (2008) In: Michard, A., O. Saddiqi, A. Chalouan, and D. Frizone de 
Lamotte (eds), Continental Evolution: The Geology of Morocco. Lecture Notes in Earth Sciences, Springer, Berlin, 203-302.

Díaz, J., Gallart, J., Villaseñor, A., Mancilla, F., Pazos, A., Córdoba, D., Pulgar, J.A., Ibarra, P., Harnafi, M., (2010). Mantle dynamics beneath the Gibraltar Arc (western Mediterranean) from shear-wave splitting measurements on a dense seismic array, Geophys. Res. Lett., 37(L18304), doi:10.1029/2010GL044201

Díaz, J., A. Gil, and J. Gallart, (2013), Uppermost mantle seismic velocity and anisotropy in the Euro-Mediterranean region from Pn and Sn tomography, Geophys. J. Int., 192, 310-325

Díaz J., and J. Gallart, (2014), Seismic anisotropy from the Variscan core of Iberia to the Western African Craton: New constrains on upper mantle flow at regional scales. Earth Planet. Sci. Lett., 394, 48-47, doi:10.1016/j.eps1.2014.03.005

El Moudnib, L., Villasenor, A., Harnafi, M., Gallart, J., Serrano, I., Córdoba, D., Pulgar, J.A., Ibarra, P., Himmi, M.M., Chourak, M. (2015), Crust structure of the Betic-Rif system, western Mediterranean, from local earthquake tomography. Tectonophysics, 643, 94-115, 
570 Faccenna, C., C. Piromallo, A. Crespo-Blanc, L. Jolivet, F. Rossetti (2004). Lateral slab 571 deformation and the origin of the Western Mediterranean arcs. Tectonics 23. 572 doi:10.1029/2002TC001488.

574 Fadil, A., P. Vernant, S. McClusky, R. Reilinger, F. Gomez, D. B. Sari, T. Mourabit, K. L. 575 Feigl, and M. Barazangi (2006), Active tectonics of the western Mediterranean: GPS evidence 576 for roll back of a delaminated sub-continental lithospheric slab beneath the Rif mountains, 577 Geology, 34, 529-532, doi:10.1130/G22291.1.

579 Fullea, J., et al., Perturbing effects of sub-lithospheric mass anomalies in GOCE gravity 580 gradientand other gravity data modelling: Application to the Atlantic-Mediterranean transition 581 zone. Int. J. Appl. Earth Observ. Geoinf. (2014), doi:10.1016/j.jag.2014.02.003

583 Gallart, J., Vidal, N. and Dañobeitia, J.J. (1995). Multichannel seismic image of the crustal 584 thinning at the NE Iberian margin combining normal and wide angle reflection data. 585 Geophysical Research Letters, 22, 4, 489-492. Westmed Team (2007). "Probing the deep structure of the Eastern Alboran Basin (Western Mediterranean) by wide-angle seismics”. EGU General Assembly. Wien. 
Gracia, E., C.R. Ranero, I. Grevemeryer, The WestMed, TopoMed, and GEomargen-1 cruise parties (2012), Seismic Images and Wide-angle Velocity constrains of the structure and geodynamic origin of the Gibraltar Arc system: A geological interpretation of the Gulf of Cadiz imbricated wedge, the western and eastern Alboran basins, and the South-Balearic basin. Geophys. Res. Abs., Vol 14, EGU 2012-8209 presented at 2043 spring Meeting EGU, Vienna, Austria, April

600 beneath the Rif Cordillera, North Morocco, from the RIFSIS wide-angle reflection seismic experiment. Geochem. Geophys. Geosyst., 15, 4712-4733, doi:10.1002/2014GC005485.

604

Gutscher, M.A., J. Malod, J.P. Rehault, I. Contrcci, F. Klingelhoefer, L. Mendes-Victor, and W. Spakman (2002), Evidence for active subduction beneath Gibraltar, Geology, 30, 1071-1074

607

Hatzfeld, D., and D. Bensari (1977), Grands profile sesmiques dans la région de l'arc de 609 Gibraltar, Bull. Sec. Géol. France, 7 (XIX-4), 749-756 and related filtered anomaly maps of Morocco, U.S. Geol. Surv. Open File Rep., 88-517.

614 Jolivet, L., C. Faccenna and C. Piromallo (2009). From mantle to crust: Stretching the 615 Mediterranean. Earth Planet. Sci. Lett., 285, 198-209. Mourabit, J.M. Davila, and N. Amraoui, (2011), New GPS constraints on active deformation 
621 Lonergan, L., and N. White (1997), Origin of the Betic-Rif mountain belt, Tectonics, 16, 504$622 \quad 522$, doi:10.1029/96TC03937

624 Mancilla, F.L., Diaz, J., High resolution Moho topography map beneath Iberia and Northern 625 Morocco from receiverfunction analysis, Tectonophysics (2015), 203-211, $626 \quad$ http://dx.doi.org/10.1016/j.tecto.2015.06.017

628 Mancilla, F.L., D. Stich, J. Morales, J. Julià, J, Díaz, A. Pazos, D. Córdoba, J.A. Pulgar, P. 629 Ibarra, M. Harnafi, and F. Gonzalez-Lodeiro (2012), Crustal thickness variations in Northern 630 Morocco, J. Geophys. Res., 177, B02312, doi:10.1029/2011JB008608

636 Palano, M., P. Gonzalez, J. Fernandez (2013). Strain and stress fields along the Gibraltar 637 Orogenic Arc: constraints on active geodynamics Gondwana Res., 23 (2013), pp. 1071-1088 638 doi:10.1016/j.gr.2012.05.021

640 Palomeras, I., S. Thurner, A. Levander, K. Liu, A. Villaseñor, R. Carbonell, M. Harnafi (2014), 641 Finite-frequence Rayleigh wave tomography of the western Mediterranean: Mapping its 642 lithospheric structure, G3, 15 (1), 140-160, doi:10.1002/2013GC004861 
644 Pérouse, E., P. Vernant, J. Chery, R. Reilinger, and S. McClusku, (2010), Active surface 645 deformation and sub-lithospheric processes in the western Mediterranean constrained by 646 numerical models, Geologym 38(9), 823-826, doi: 10.1130/G30963.1

648 Petit, C., Le Pourhiet, L., Scalabrino, B., Corsini, M., Bonnin, M. and Romagny, A. (2015). 649 Crustal structure and gravity anomalies beneath the Rif, northern Morocco: implications for 650 the current tectonics of the Alboran region. Geophys. J. Int. 202 (1): 640-652. doi: $651 \quad 10.1093 / \mathrm{gji} / \mathrm{ggv} 169$

653 Platt, J.P. and R.L.M. Vissers (1989). Extensional collapse of thickened continental 654 lithosphere: A hypothesis for the Alboran Sea and Gibraltar arc, Geology, 17, 540-543.

655

656 Platt, J.P., Th.W. Becker, R.L. Evans, E.D. Humphreys, C.T. Lee, and A. Levander (2008), 657 PICASSO:testing models for upper mantle processes beneath the Alboran Basins and the 658 Gibraltar Arc (Western Mediterranean), Geol. Soc. Am. Abstrat. Prog., 40(6), 273.

660 Platt, J.P., Behr W, Johanesen, K., and Williams R. (2013) The Betic-Rif Arc and Its Orogenic 661 Hinterland: A Review. Annual Review of Earth and Planetary Sciences Vol. 41: 313-357 doi: $662 \quad 10.1146 /$ annurev-earth-050212-123951

664 Romagny, A., Ph. Münch, J.-J. Cornée, M. Corsini, A. Azdimousa, M.C. Meline-Dobrinescu, 665 H. Drinia, M. Bonno, N. Arnaud, P. Monié, F. Quillévéré and A. Ben Moussa (2014), Late 666 Miocene to present-day exhumation and uplift of the Internal Zone of the Rif Chain: Insights 667 from low temperature thremochronometry and basin analysis, Journal of Geodynamics, 77, 39$668 \quad$ 55, doi:10.1016/j.jog.2014.01.006 
670 Rosenbaum, G., Lister, G.S., (2004). Neogene and Quaternary rollback evolution of the 671 Tyrrhenian Sea, the Apennines, and the Sicilian Maghrebides. Tectonics 23, TC1013. 672 doi:10.1029/2003TC001518.

674 Royden, L.H (1993), Evolution of retreating subduction beoundaries formed during continental 675 collision, Tectonics, 12, 629-638, doi:10.1029/92TC02641

676

677 Seber, D., M. Barazangi, B. A. Ibenbrahim, and A. Demnati (1996), Geophysical evidence for 678 lithospheric delamination beneath the Alboran Sea and Rif-Betic Mountains, Nature, 379, 785$679 \quad 790$

680

681 Serrano, I., T.M. Hearn, J. Morales and F. Torcal (2005). Seismic anisotropy and velocity 682 structure beneath the southern half of the Iberian Peninsula. Phys. Earth and Planet. Int, , 150, $683 \quad 317-330$.

685 Spada, M., Bianchi, I., Kissling, E., Piana Agostinetti, A., Wiemer, S. (2013). Combining 686 controlled-source seismology and receiver function information to derive 3-D Moho 687 topography for Italy. Geophys. J. Int., 194, 1050-10698, doi: 10.1093/gji/ggt148

689 Spakman, W. and M.J.R. Wortel, (2004). A tomographic view on western Mediterranean 690 geodynamics. In: Ziegler, P. [Ed.], The TRANSMED Atlas — The Mediterranean region from 691 crust to mantle. Springer, Berlin Heidelberg, pp. 31-52

693 Thurner, S., I. Palomeras, A. Levander, R. Carbonell and L. Cin-ty (2014), Evidence for 
694 Ongoing Lithospheric Removal in the Western Mediterranean: Ps Receiver Function Results 695 from the PICASSO Project, G3, doi:10.002/201GC005124

696

697 Torné, M., M. Fernàndez, M. C. Comas, and J. I. Soto (2000), Lithospheric structure beneath 698 the Alboran Basin: Results from 3D gravity modeling and tectonic relevance, J. Geophys. Res., 699 105(B2), 3209-3228, doi:10.1029/1999JB900281.

700

701 Vergés, J., and M. Fernàndez (2012), Tethys-Atlantic interaction along the Iberia-Africa plate 702 boundary: The Betic-Rif orogenic system, Tectonophysics, 579, 144-172, 703 doi:101016/j.tecto.2012.08.032

704

705 Vernant, P., A. Fadil, T. Mourabit, D. Ouazar, A. Koulali, J.M. Davila, J. Garate, S. McClusky, 706 and R. Reilinger, (2010), Geodetid constraints on active tectonics of the Western 707 Mediterranean: Implications for the kinematics and dynamics of the Nubia-Eurasia plate 708 boundary zone,Journal of Geodynamics, 49, 123-129

709

710 Wessel, P., W. H. F. Smith, R. Scharroo, J. F. Luis, and F. Wobbe, (2013) Generic Mapping 711 Tools: Improved version released, EOS Trans. AGU, 94, 409-410.

712

713 Wigger, P., G. Asch, P. Giese, W. D. Heinsohn, S. O. E. Alami, and F. Ramdami (1992), Crustal 714 structure along a traverse across the Middle and High Atlas mountains derived from seismic 715 refraction studies, Geol. Rundsch., 81(1), 237-248, doi:10.1007/BF01764552.

716

717 Working Group For Deep Seismic Sounding In Alboran 1974, (1978). Crustal seismic profiles 718 in the Alboran sea-preliminary results. Pageoph, 116, 166-180. 
720 Zeck, H.P. (1996). Betic-Rif orogeny: Subduction of Mesozoic Tethys lithosphere under 721 eastward drifting Iberia, slab detachment shortly before $22 \mathrm{Ma}$ and subsequent uplift and 722 extensional tectonics, Tectonophysics, 254, 1-16Zelt, C.A, and R.B. Smith (1992), Seismic 723 traveltime inversion fro 2-D crustal velocity structure, Geophys. J. Int., 108, 16-34

725 Zeyen, H., P. Ayarza, M. Fernàndez, and A. Rimi (2005), Lithospheric structure under the 726 western African-European plate boundary: A transect across the Atlas Mountains and the Gulf 727 of Cadiz, Tectonics, 24, TC2001, doi:10.1029/2004TC001639 


\section{Figure Captions}

Figure 1: a) Geometry of the wide-angle seismic reflection experiments. Shot point locations are marked by yellow stars. The red dots indicate the location of the seismic recorders while the black dots indicate the CMP (Common Mid Points) used for the low-fold wide-angle stacks. Dashed black lines labeled p17-p19-p21 show the contributing GASSIS offshore profiles. b) Bouguer anomaly map. White squares denote BB seismic stations from the TopoIberia experiment, yellow circles are from PICASSO stations and black squares are for the new stations deployed within the RIFSIS project.

Figure 2: Low fold wide-angle stacks along profiles EW (upper panel) and NS (lower panel). Data is presented using an hyperbolic time reduction $\boldsymbol{H T R}=\left(\boldsymbol{t}-\sqrt{\boldsymbol{t}^{2}-\boldsymbol{x}^{2} / \boldsymbol{v}^{2}}\right.$ with $\mathrm{v}=6.2$ km/s. Dashed red lines indicate the Moho reflected energy (PmP phases) along each profile.

Figure 3: Low fold wide-angle stacks of the offline shot R2 recorded along profile EW (upper panel) and of the offline shot R4 recorded along profile NS (lower panel). Data presented using an hyperbolic time reduction $\boldsymbol{H T R}=\left(\boldsymbol{t}-\sqrt{\boldsymbol{t}^{2}-\boldsymbol{x}^{2} / \boldsymbol{v}^{2}}\right.$ with $\mathrm{v}=6.2 \mathrm{~km} / \mathrm{s}$. Dashed red lines indicate the Moho reflected energy (PmP phases) along each profile.

Figure 4: a) Ray tracing modeling of the main N-S and E-W wide angle profiles (Gil et al., 2014). b) Upper panel: Shot R3 recorded at the NW-SE lines 4000 and 5000 shown in the inset. Lower panel: Shot R5 recorded at the NE-SW line 3000 shown in the inset. Numbers ontop the traces show offsets. Times are reduced using v=6.0 km/s. 
$754 \quad$ Figure 5: $\mathrm{H}-\kappa$ analysis for some characteristic stations. a) Station PM07, located in the internal 755 Rif. b) station M416, showing a complex case in the thickened area c) Station M418, located 756 close to the Nekkor fault area and depicting a thinner crust d) PM20, close to the Middle Atlas, 757 also showing a rather thin crust. The inset map shows the position of the stations.

758

759 Figure 6: Moho depth maps inferred from wide-angle experiments (a) and RF analysis (b) 760 beneath Northern Morocco. Numbers show the Moho depth values at the points where a 761 measurement is available. Color grid interpolates those points using a nearest neighbor 762 algorithm.

$764 \quad$ Figure 7: a) Moho depth map as inferred from the combined results from controlled source 765 experiments and RF data. b) 3D view of the same map. Reddish colors show the thinner zones 766 beneath the Alboran Sea and the east Morocco. Deep blue colors show the deep crustal 767 thickening beneath the Rif, where crustal thickness exceeds $50 \mathrm{~km}$.

769 Figure 8: Earthquakes with magnitude > 2, as reported by the Instituto Geográfico Nacional 770 catalogue in the period 2000-2014, overprinting the new crustal thickness map. White dots are 771 for event with hypocenters above $40 \mathrm{~km}$ depth, black dots denote deeper events. 
a)

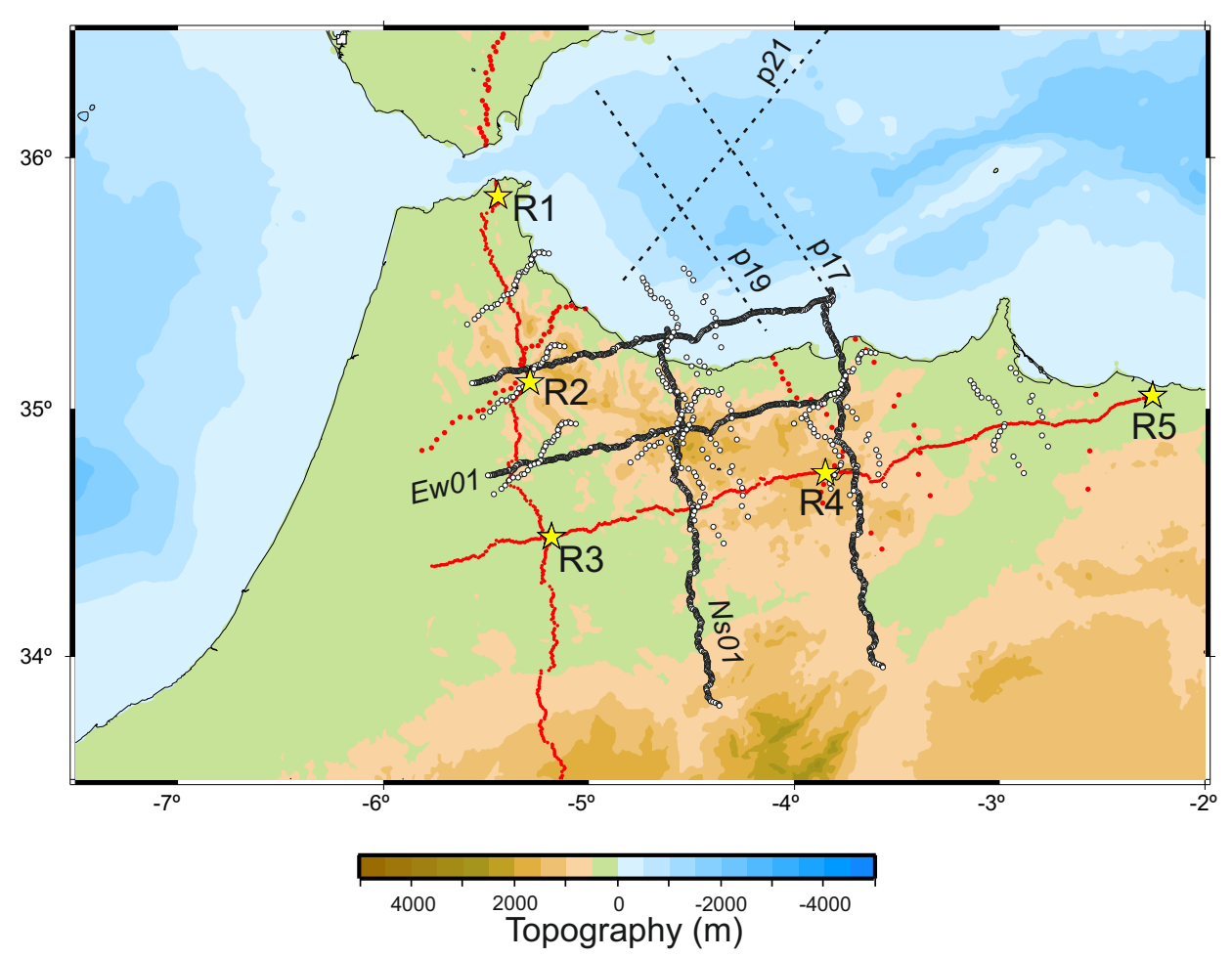

b)

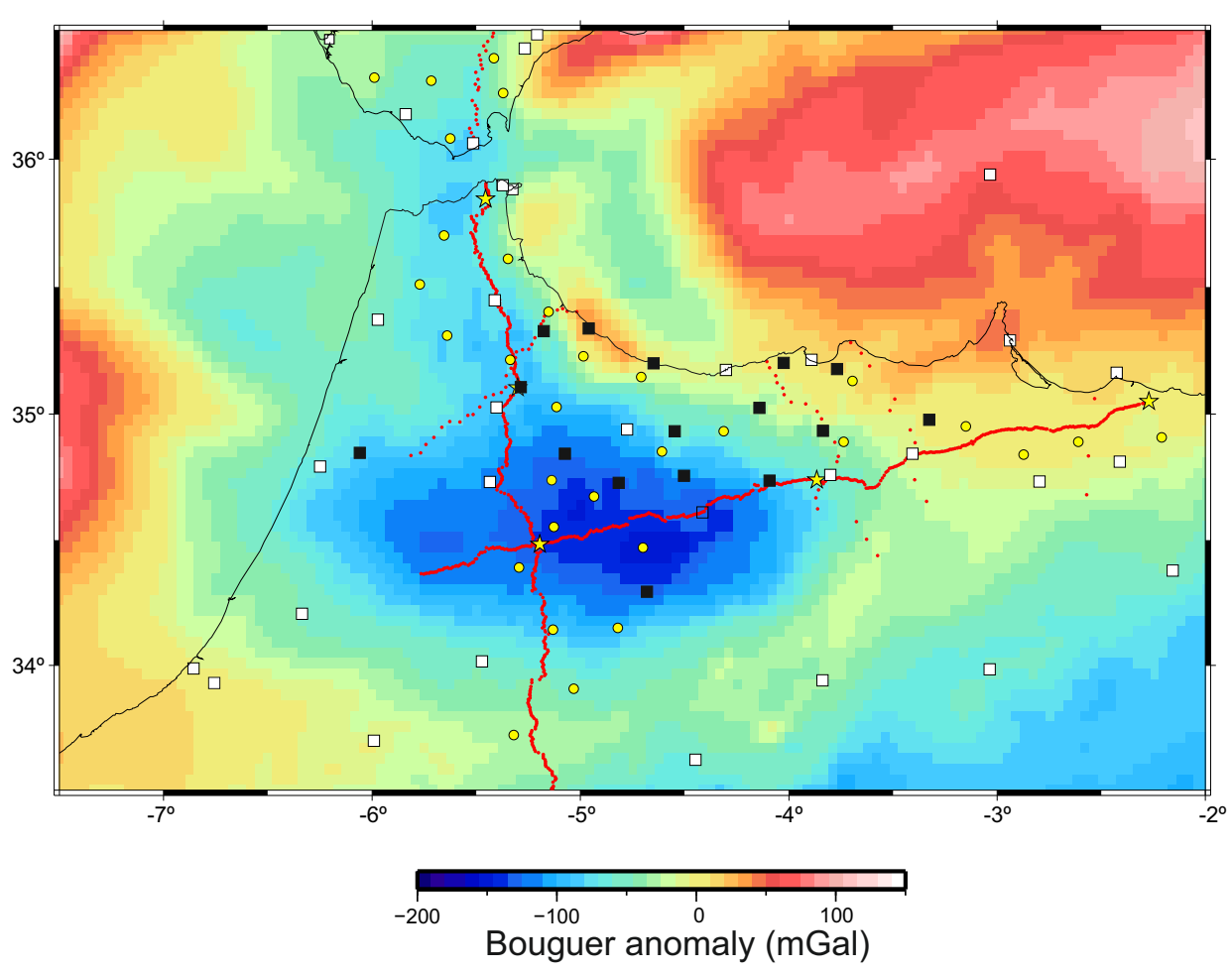

\section{Figure 1:}

a) Geometry of the wide-angle seismic reflection experiments. Shot point locations are marked by yellow stars. The red dots indicate the location of the seismic recorders while the white dots indicate the CMP (Common Mid Points) used for the low-fold wide-angle stacks. Dashed black lines labeled p17-p19-p21 show the contributing GASSIS offshore profiles.

b) Bouguer anomaly map. White squares denote BB seismic stations from the Topolberia experiment, yellow circles are from PICASSO stations and black squares are for the new stations deployed within the RIFSIS project. 

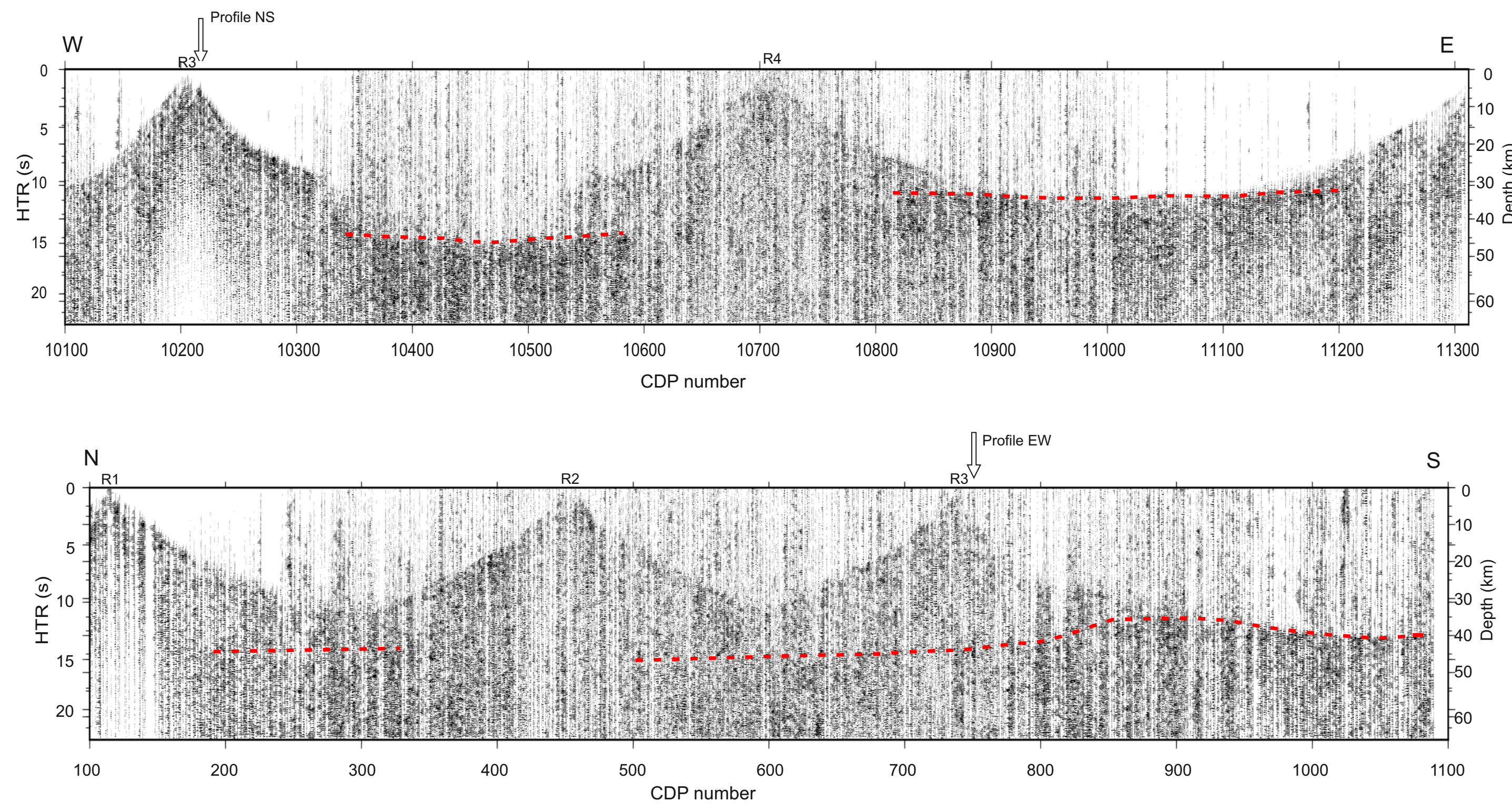

Figure 2: Low fold wide-angle stacks along profiles EW (upper panel) and NS (lower panel). Data is presented using an hyperbolic time reduction HTR $=\mathrm{t}-\left(\mathrm{t}^{2}-\mathrm{x}^{2} / \mathrm{v}^{2}\right)^{1 / 2}$ with $\mathrm{v}=6.2 \mathrm{~km} / \mathrm{s}$. Dashed red lines indicate the Moho reflected energy (PmP phases) along each profile. 


\section{Figure 3 (with caption below and on the same page)}
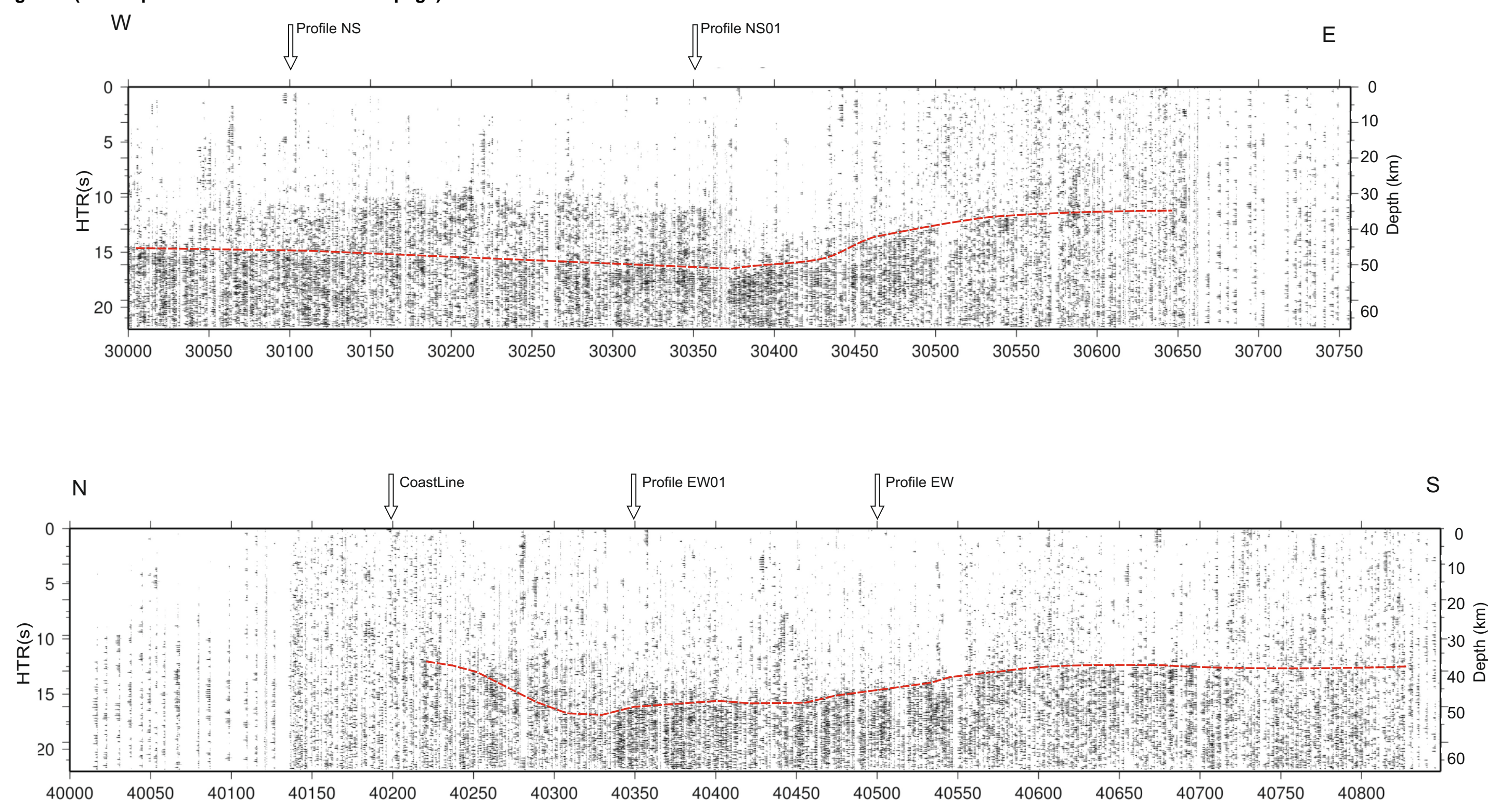

Figure 3: Low fold wide-angle stacks of the offline shot R2 recorded along profile EW (upper panel) and of the offline shot R4 recorded along profile NS (lower panel). Data presented using an hyperbolic time reduction $H T R=t-\left(t^{2}-x^{2} / v^{2}\right)^{1 / 2}$ with $v=6.2 \mathrm{~km} / \mathrm{s}$. Dashed red lines indicate the Moho reflected energy (PmP phases) along each profile. 
a)

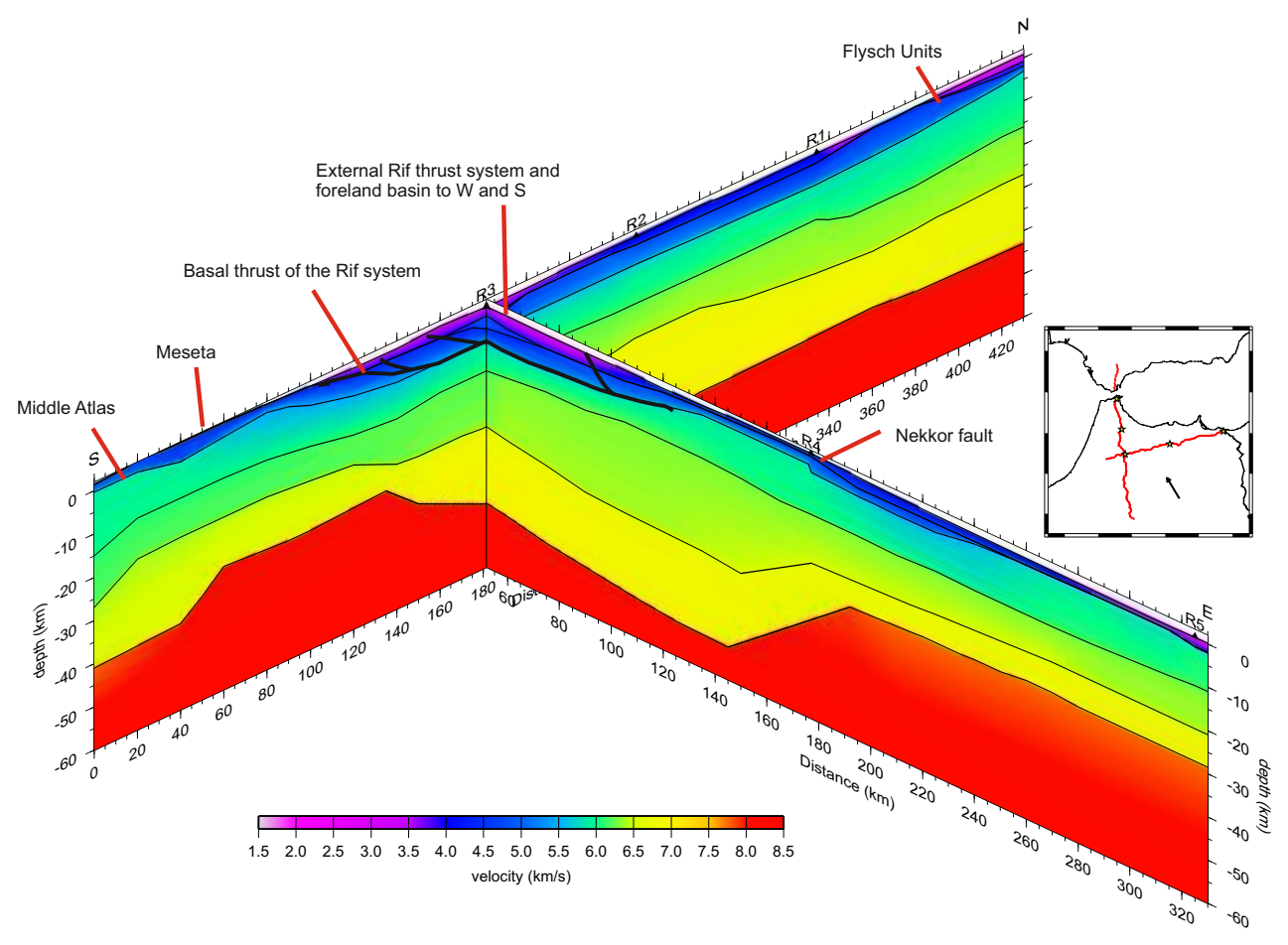

Figure 4

a) Ray tracing modeling of the main NS and E-W wide angle profiles (Gil et al., 2014)

b) Examples of PmP picking on the auxiliary profiles. Upper panel: Shot R3 recorded at the NW-SE lines 5000 and 4000 shown in the inset. Lower panel: Shot R4 recorded at the NE-SW line 3000 shown in the inset.

Numbers ontop the traces show offsets. Times are reduced using $\mathrm{v}=6.0$ $\mathrm{km} / \mathrm{s}$ b)
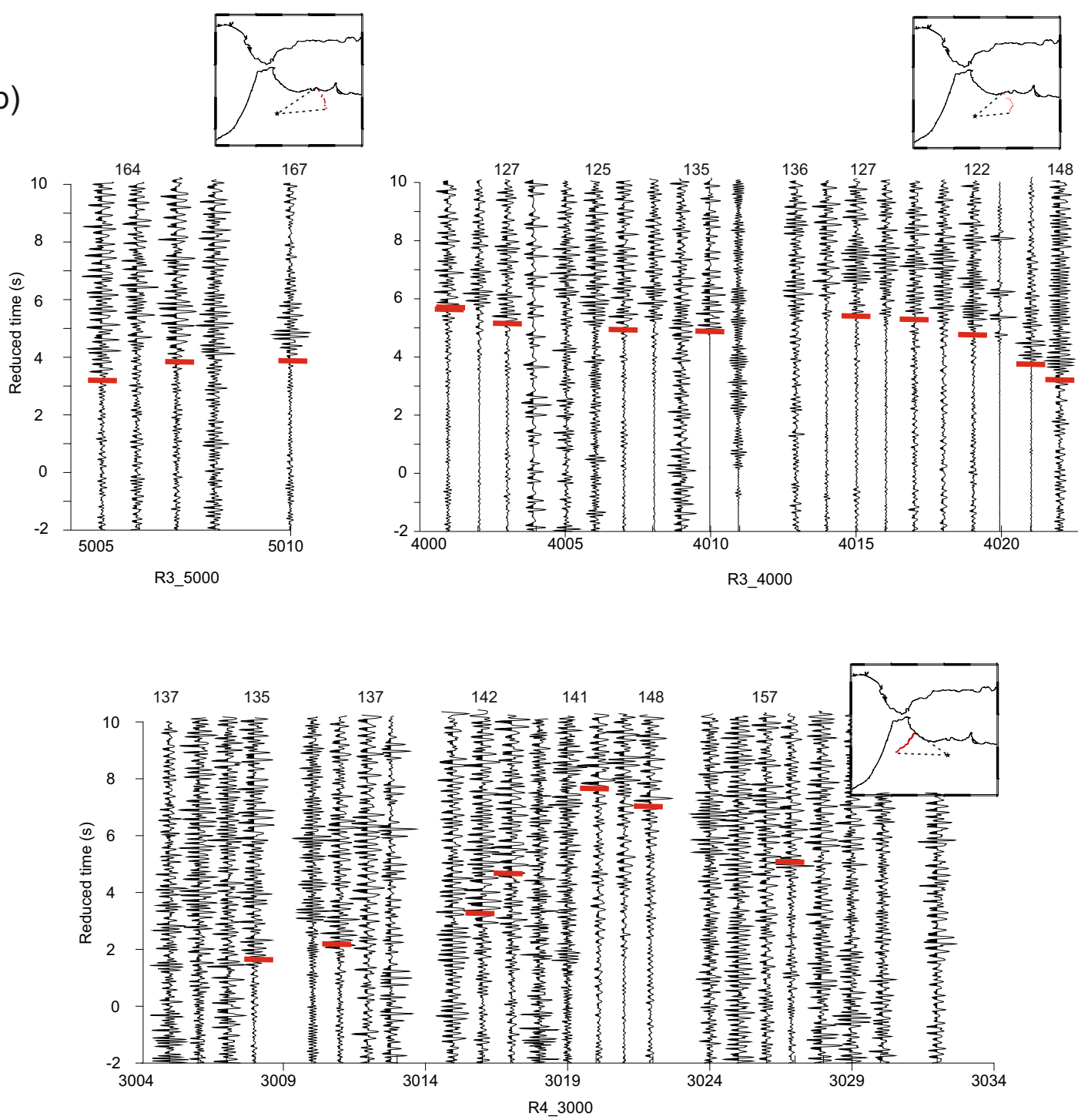


\section{Figure 5 (with caption below and on the same page)}

a)

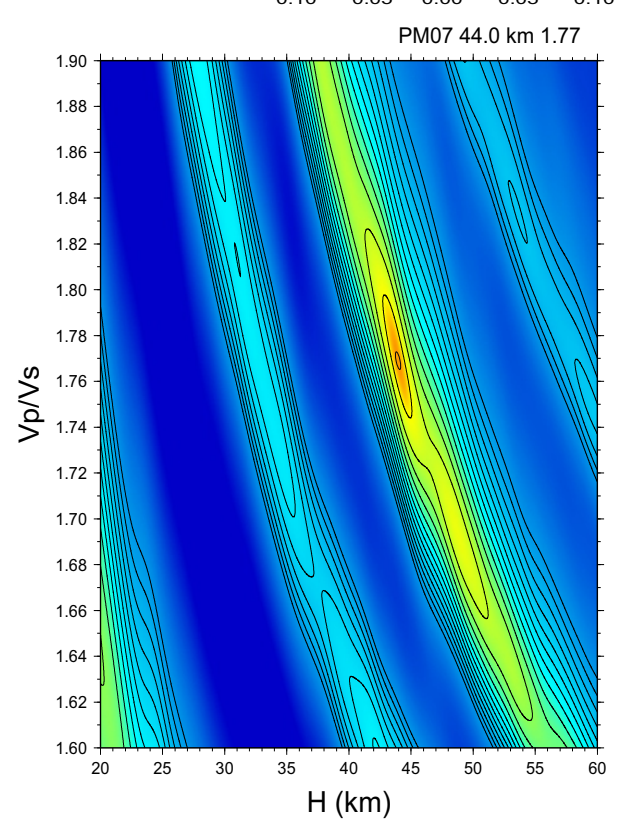

c)

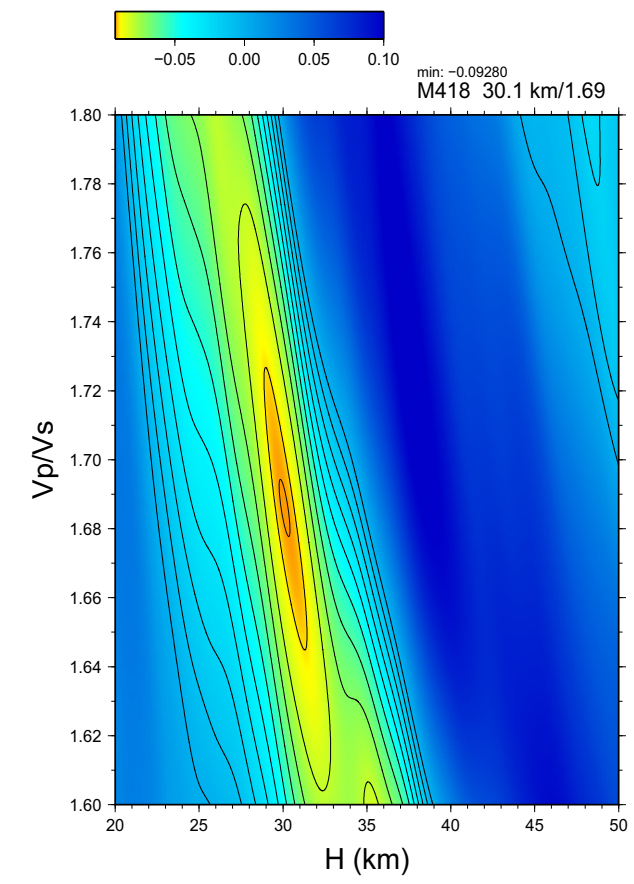

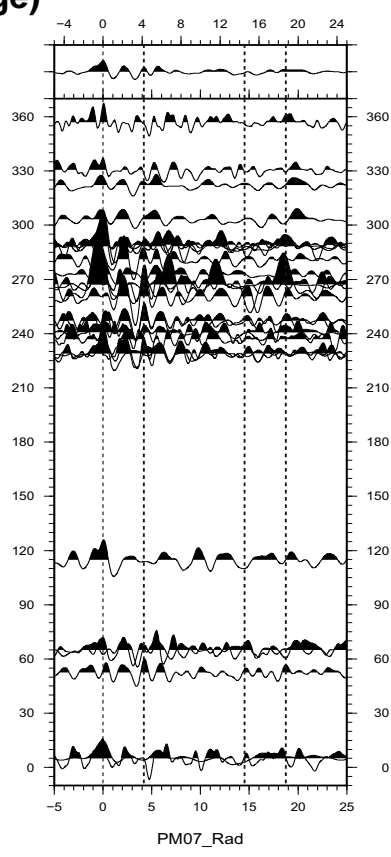

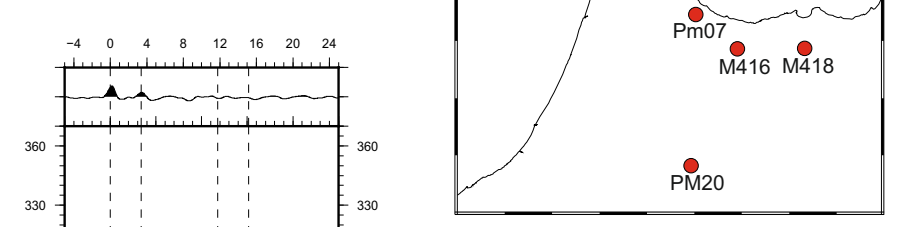

b)

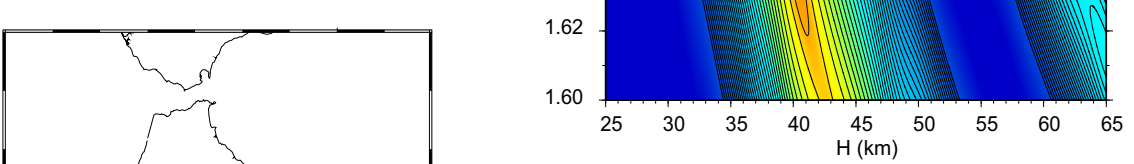

d)

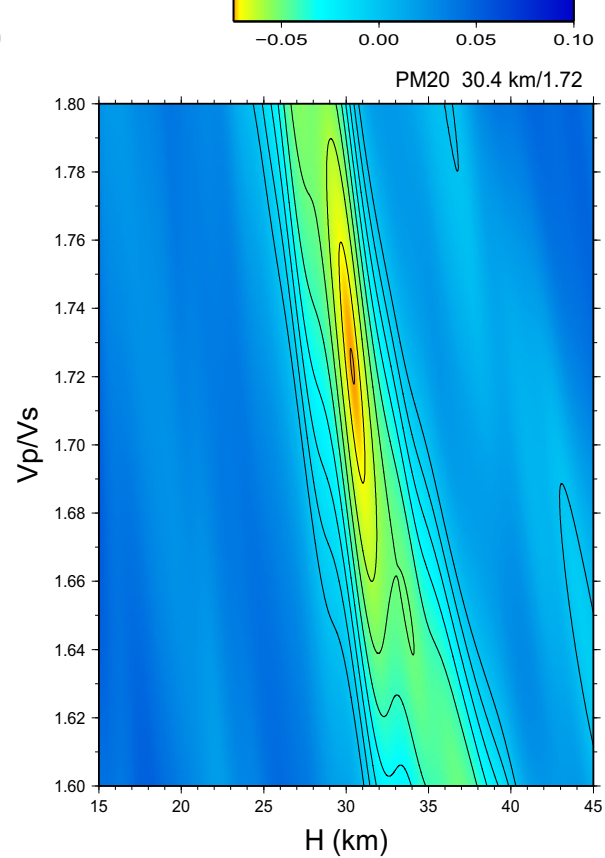

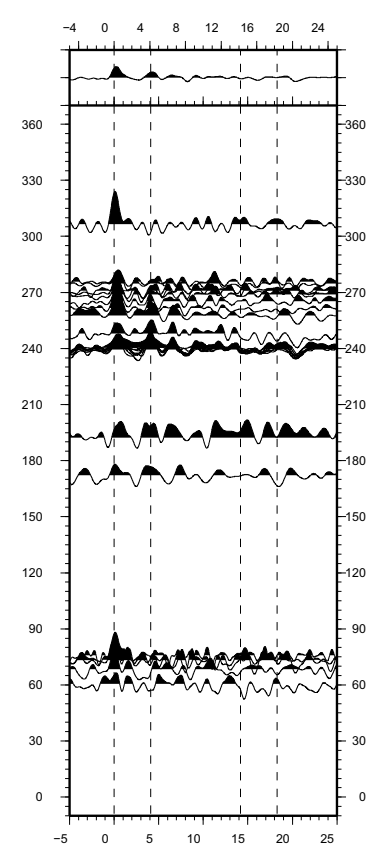

M416a_Rad

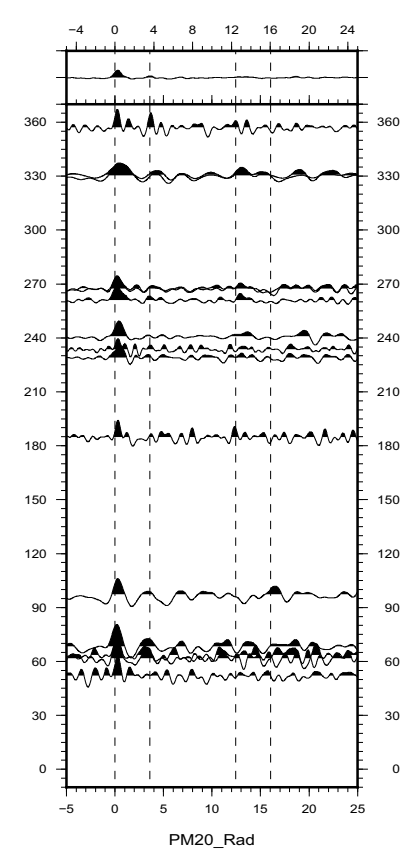

Figure 5: $\mathrm{H}-\kappa$ analysis for some characteristic stations. a) Station PM07, located in the internal Rif. b) station M416, showing a complex case, in the thickened area. c) Station M418, located close to the Nekkor fault area and depicting a thinner crust d) PM20, located close to the Middle Atlas, also showing a rather thin crust. The inset map shows the position of the stations. 
a)

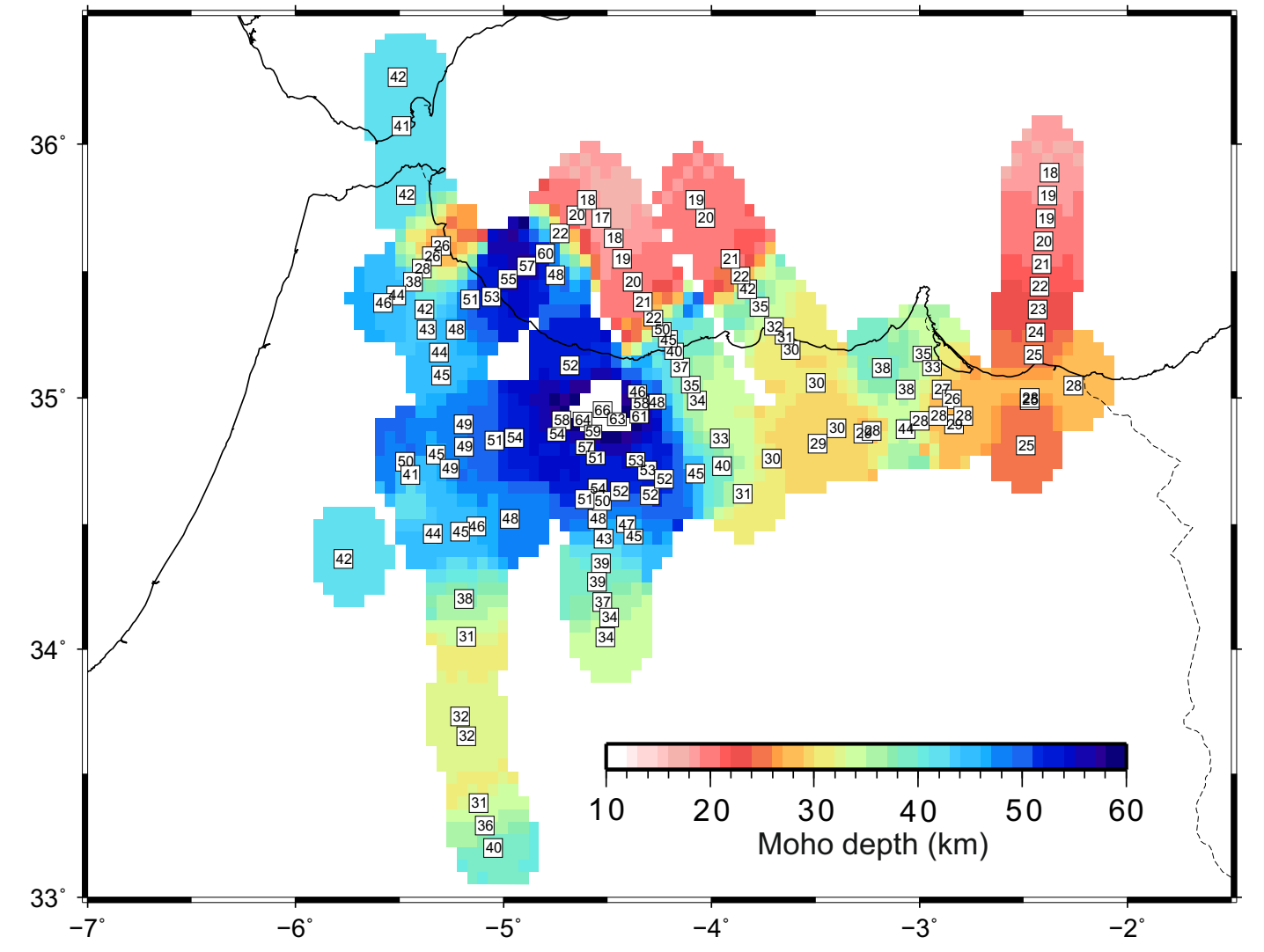

b)

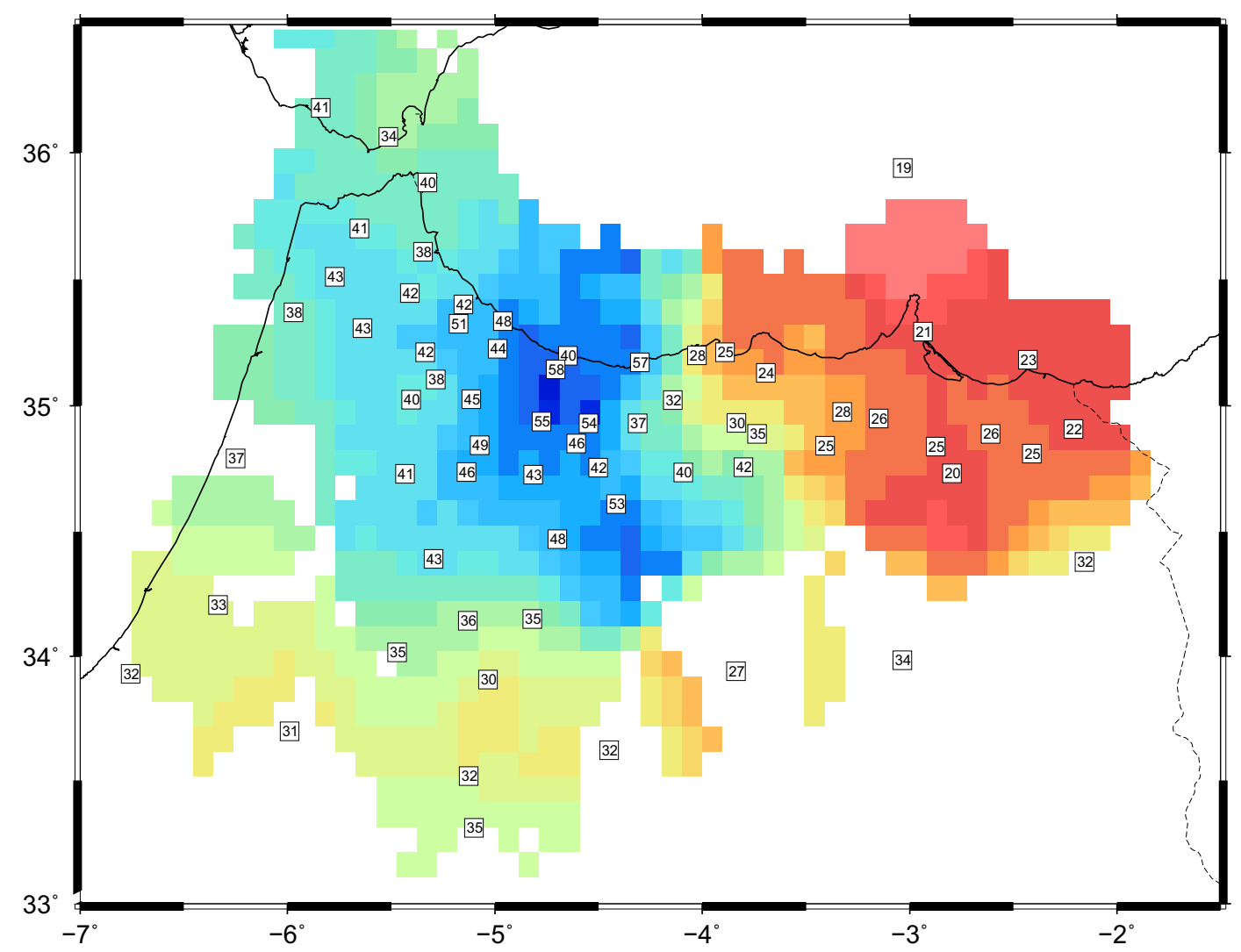

Figure 6: Moho depth maps inferred from wide-angle experiments (a) and RF analysis (b) beneath Northern Morocco. Numbers show the Moho depth values at the points where a measurement is available. Color grid interpolates those points using a nearest neighbor algorithm. 
a)

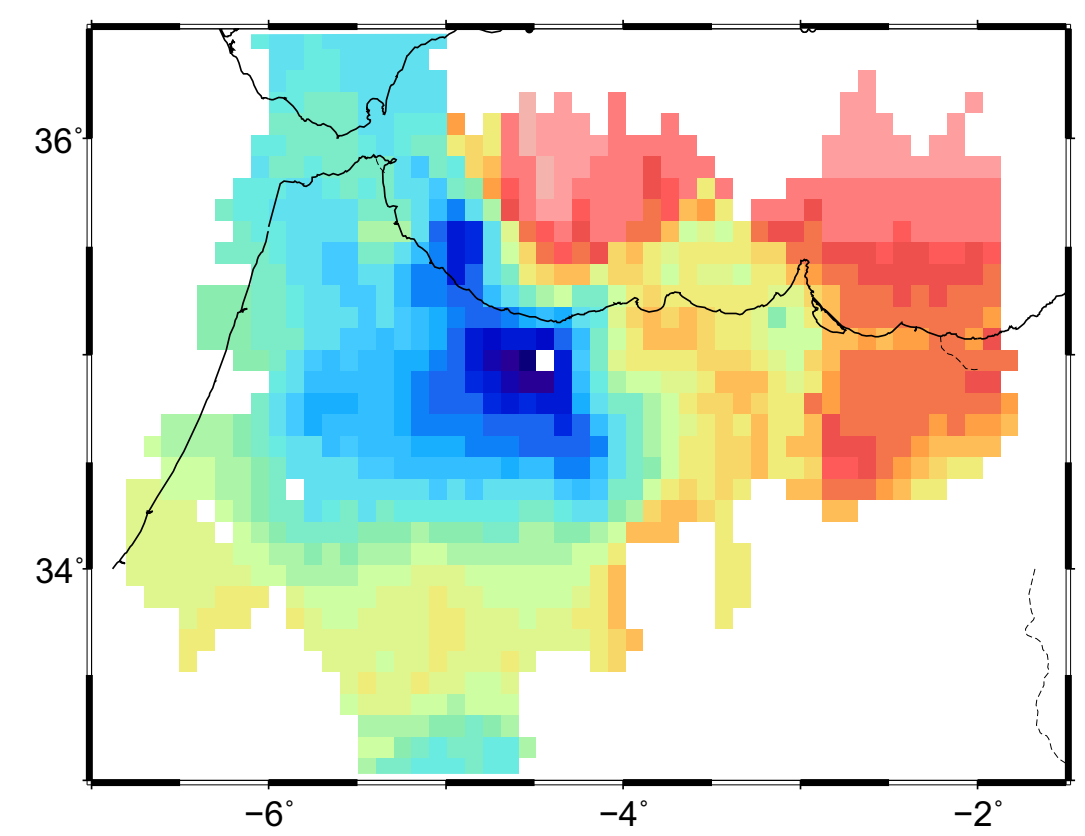

10

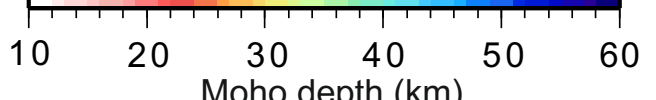

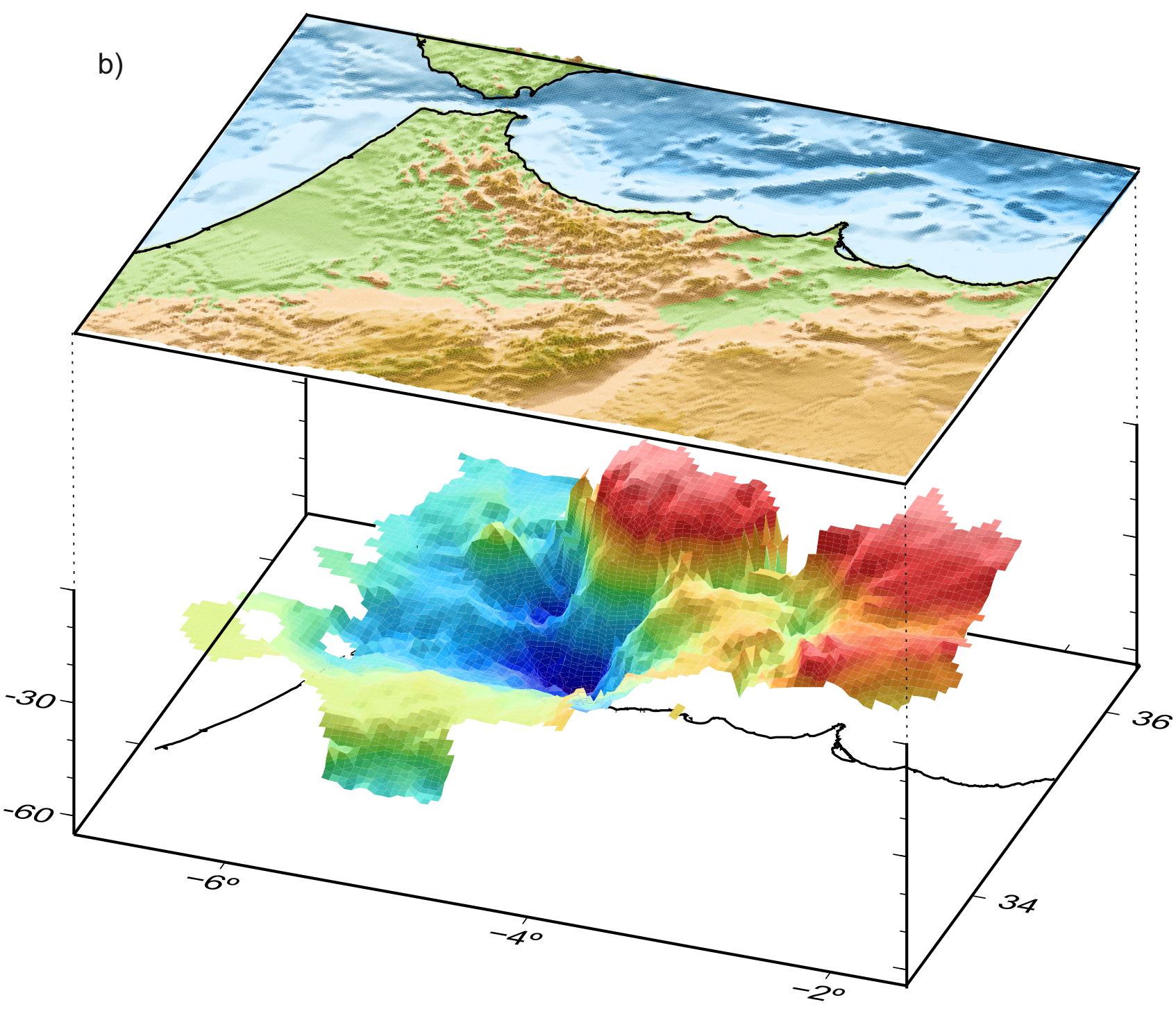

Figure 7: a) Moho depth map as inferred from the combined results from controlled source experiments and RF data. b) 3D view of the same map. Reddish colors show the thinner zones beneath the Alboran Sea and the east Morocco. Deep blue colors show the deep crustal thickening beneath the Rif, where crustal thickness exceeds $50 \mathrm{~km}$. 


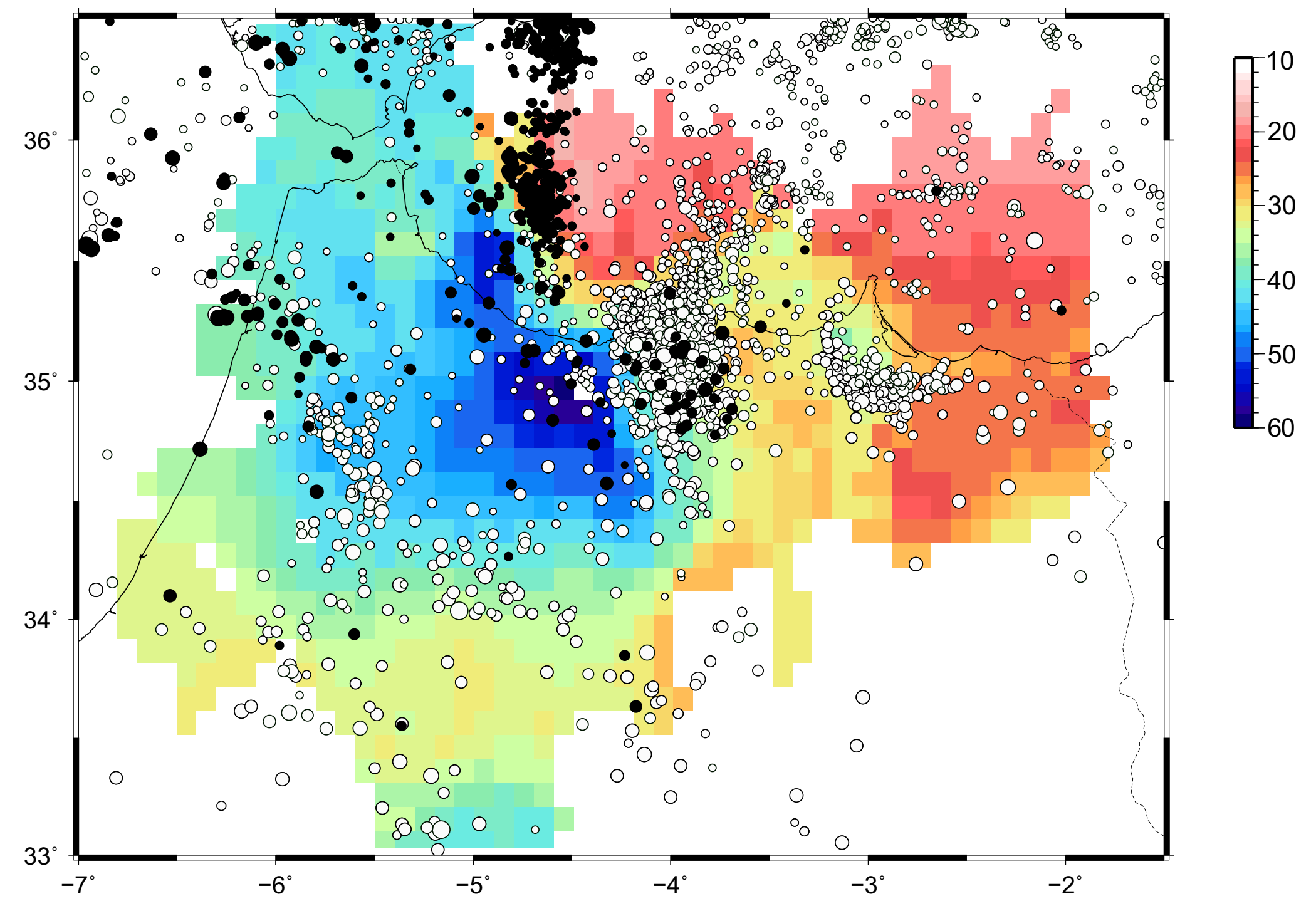

Figure 8: Earthquakes with magnitude > 2, as reported by the Instituto Geográfico Nacional catalogue in the period 2000-2014, overprinting the new crustal thickness map. White dots are for event with hypocenters above $40 \mathrm{~km}$ depth, black dots denote deeper events. 